Prepared for the U.S. Department of Energy

under Contract DE-AC05-76RL01830

\title{
Hanford Tank Farms Waste Certification Flow Loop Test Plan for Instrument Evaluation
}

\author{
JA Bamberger \\ JR Bontha \\ HE Adkins \\ CA Burns
}

January 2010
BE Wells

J Blanchard

KM Denslow

MS Greenwood
GP Morgen 


\title{
DISCLAIMER
}

This report was prepared as an account of work sponsored by an agency of the United States Government. Neither the United States Government nor any agency thereof, nor Battelle Memorial Institute, nor any of their employees, makes any warranty, express or implied, or assumes any legal liability or responsibility for the accuracy, completeness, or usefulness of any information, apparatus, product, or process disclosed, or represents that its use would not infringe privately owned rights. Reference herein to any specific commercial product, process, or service by trade name, trademark, manufacturer, or otherwise does not necessarily constitute or imply its endorsement, recommendation, or favoring by the United States Government or any agency thereof, or Battelle Memorial Institute. The views and opinions of authors expressed herein do not necessarily state or reflect those of the United States Government or any agency thereof.

\author{
PACIFIC NORTHWEST NATIONAL LABORATORY \\ operated by \\ BATTELLE \\ for the \\ UNITED STATES DEPARTMENT OF ENERGY \\ under Contract DE-AC05-76RL01830
}

Printed in the United States of America

Available to DOE and DOE contractors from the

Office of Scientific and Technical Information,

P.O. Box 62, Oak Ridge, TN 37831-0062;

ph: (865) 576-8401

fax: $(865) 576-5728$

email: reports@adonis.osti.gov

\author{
Available to the public from the National Technical Information Service, \\ U.S. Department of Commerce, 5285 Port Royal Rd., Springfield, VA 22161 \\ ph: (800) 553-6847 \\ fax: (703) 605-6900 \\ email: orders@ntis.fedworld.gov \\ online ordering: http://www.ntis.gov/ordering.htm
}

This document was printed on recycled paper.

$$
(9 / 2003)
$$




\title{
Hanford Tank Farms Waste Certification Flow Loop Test Plan for Instrument Evaluation
}

\author{
JA Bamberger \\ JR Bontha \\ HE Adkins \\ BE Wells \\ J Blanchard \\ KM Denslow \\ MS Greenwood \\ GP Morgen
}

January 2010

Prepared for

the U.S. Department of Energy

under Contract DE-AC05-76RL01830

Pacific Northwest National Laboratory

Richland, Washington 99352 



\begin{abstract}
Future Hanford Tank Farm operations will involve transfer of wastes from double-shell tanks to the Waste Treatment Plant. As the U.S. Department of Energy contractor for Tank Farm Operations, Washington River Protection Solutions anticipates the need to certify that waste transfers comply with contractual requirements. This test plan describes the approach for evaluating three ultrasonic instruments that have potential to detect the onset of flow stratification and critical suspension velocity during pipeline transport. The testing will be conducted in an existing pipe loop in Pacific Northwest National Laboratory's facility that was modified to accommodate the testing of the three ultrasonic instruments over a range of simulated waste properties and flow conditions. The testing phases, test matrix, types of simulants, and range of testing conditions required to evaluate the instruments are described.
\end{abstract}





\section{Acronyms and Abbreviations}

\begin{tabular}{|c|c|}
\hline CSM & cognizant space manager \\
\hline $\mathrm{D}$ & diameter, distance \\
\hline DOE & U.S. Department of Energy \\
\hline DoS & degree of suspension \\
\hline DST & double-shell tank \\
\hline ECR & environmental compliance representative \\
\hline ESH\&Q & Environment, Safety, Health, and Quality \\
\hline FBRM & focused beam reflectance measurement \\
\hline HDI & How Do I? \\
\hline HLW & high-level waste \\
\hline ICD & Interface Control Document \\
\hline ID & inside diameter \\
\hline MOA & memorandum of agreement \\
\hline OD & outer diameter \\
\hline PDLE & Process Development Laboratory - East \\
\hline PNNL & Pacific Northwest National Laboratory \\
\hline PRV & pressure relief valve \\
\hline PSD & particle size distribution \\
\hline PSDD & particle size and density distribution \\
\hline PVC & polyvinyl chloride \\
\hline QA & quality assurance \\
\hline SG & specific gravity \\
\hline SOW & statement of work \\
\hline SS & stainless steel \\
\hline UDS & undissolved solids \\
\hline UDV & ultrasonic Doppler velocimetry \\
\hline $\mathrm{V}_{\text {slurry }}$ & voltage in slurry \\
\hline $\mathrm{V}_{\text {water }}$ & voltage in water \\
\hline WAC & Waste Acceptance Criteria, Washington Administrative Code \\
\hline WFD & waste feed delivery \\
\hline WRPS & Washington River Protection Solutions \\
\hline WTP & Waste Treatment Plant \\
\hline
\end{tabular}





\section{Contents}

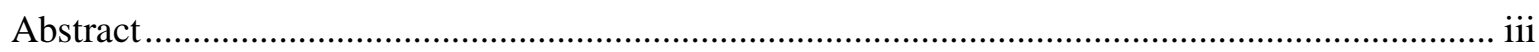

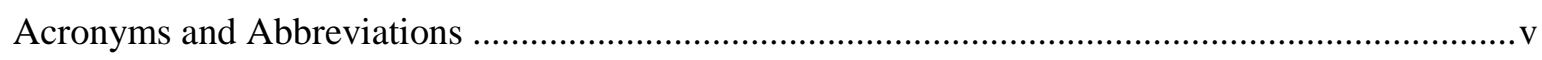

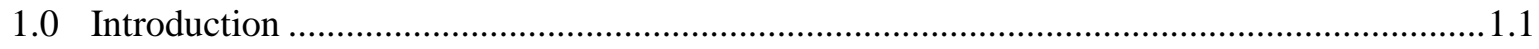

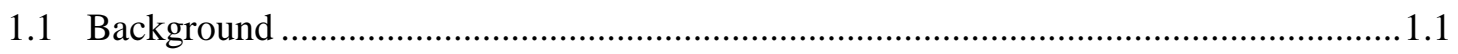

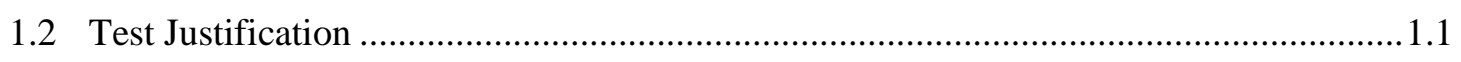

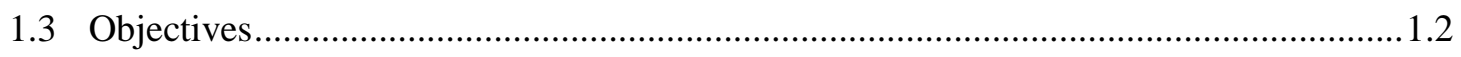

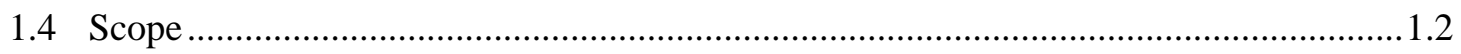

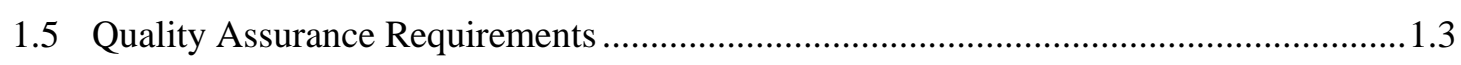

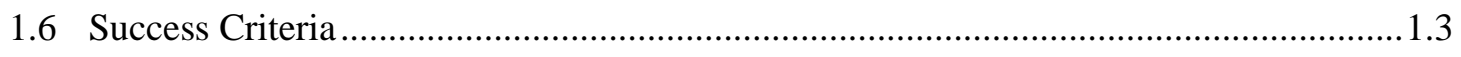

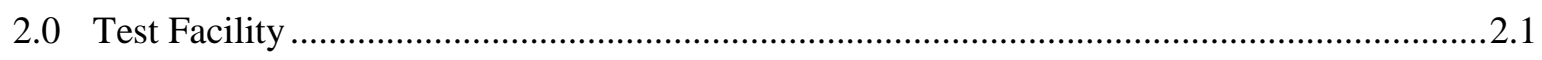

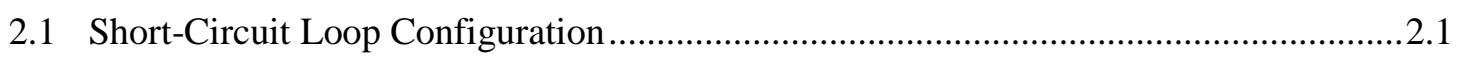

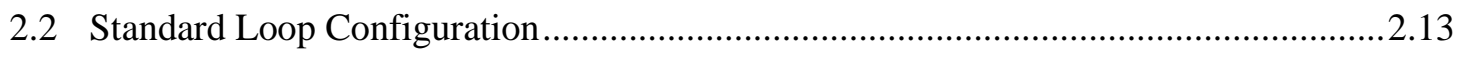

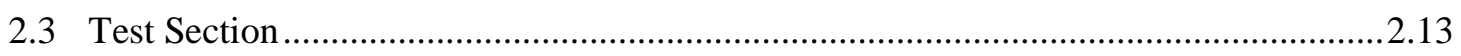

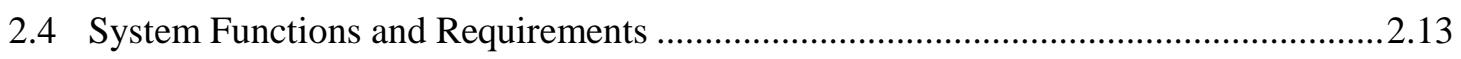

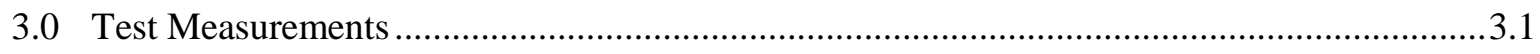

3.1 Reference Methods for Measuring or Detecting Critical Velocity …............................. 3.1

3.1.1 Resistance to Flow as Indicated by Differential Pressure ..................................... 3.1

3.1.2 Visual and Camera Imaging ............................................................................... 3.3

3.2 Development Methods for Measuring Critical Velocity …............................................3.3

3.2.1 Layer Thickness Detection with Pulse-Echo Ultrasound......................................3.3

3.2.2 Concentration Profile Measurement with Ultrasonic Attenuation ..........................3.4

3.2.3 Flow Velocity Profiling with Ultrasonic Doppler Velocimetry ............................3.5

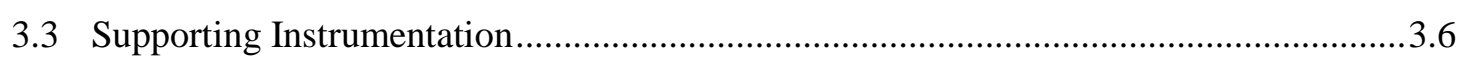

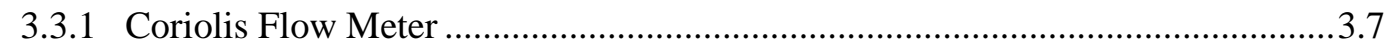

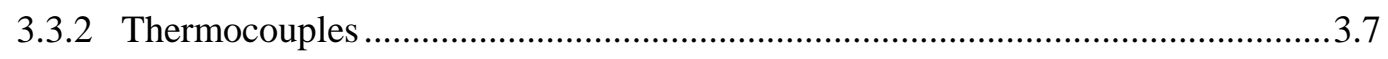

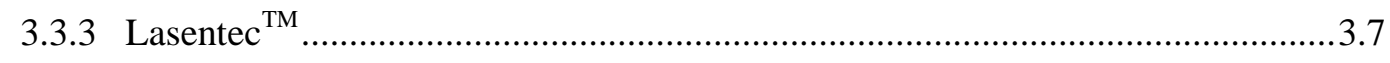

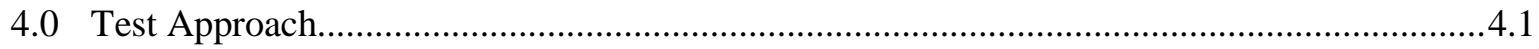

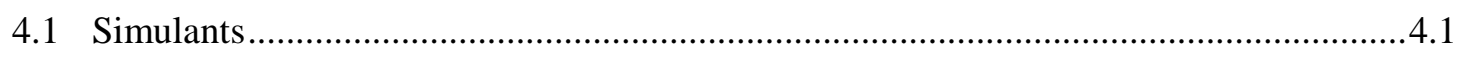

4.1.1 Noncohesive Monodisperse Particulate Simulants ............................................. 4.1

4.1.2 Noncohesive Particulate Simulants with Size or Density Distributions.................4.1

4.1.3 Non-Newtonian Simulants ............................................................................ 4.2

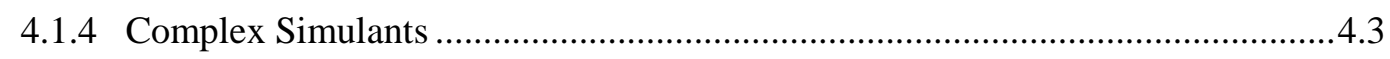

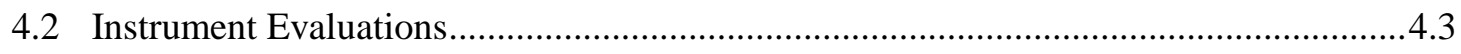

4.2.1 Bench-Scale Testing....................................................................................4.4

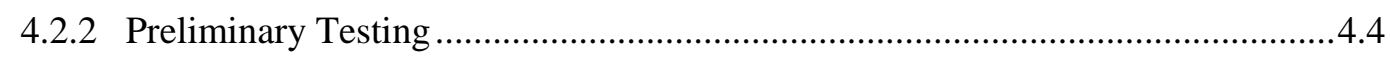

4.2.3 Instrument Validation Testing....................................................................... 4.7 
4.3 Test Procedure

5.0 Data Analysis

6.0 Waste Minimization/Management.

7.0 References

\section{Figures}

Figure 2.1. WRPS Certification Test Loop showing Short Circuit and Standard Configurations..2.3 Figure 2.2. WRPS Certification Test Loop Details 1, 2, and 3....................................................

Figure 2.3. WRPS Certification Test Loop Design Details 4, 5, and 6.......................................2.7

Figure 2.4. WRPS Certification Test Loop Design Details for Lasentec ${ }^{\mathrm{TM}}$ Sensor Mount ............2.9

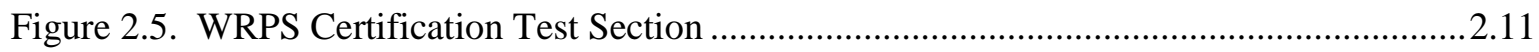

Figure 3.1. Illustration of Regions of Solids Behavior in Terms of Pressure Drop. ......................3.2

Figure 3.2. Schematic of Typical UDV Application...................................................................... 3.6

\section{Tables}

Table 2.1. Major Subsystems for the WRPS Certification Loop..............................................2.14

Table 3.1. Summary of Instruments Recommended for Evaluation .................................................6

Table 4.1. Slurries and Particles Provided for Bench-Scale Testing ............................................4.4

Table 4.2. Test Matrix for Preliminary Simulant Studies ..........................................................4.6

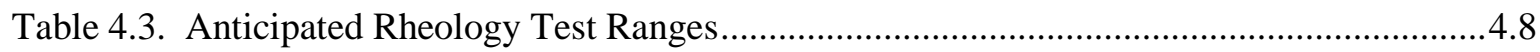

Table 4.4. Test Matrix for Critical Velocity Tests with Newtonian Simulants ...........................4.10

Table 4.5. Test Matrix for Critical Velocity Tests with Non-Newtonian/Complex Simulants.....4.11 


\subsection{Introduction}

This document presents the test plan to evaluate and select instruments needed to characterize the transport properties of Hanford double-shell tank (DST) waste before it is transferred to the Waste Treatment Plant (WTP). The capability to characterize the solids distribution during transport will determine whether the slurry properties are acceptable for delivery based on evaluation using instrumentation to detect the onset of critical velocity as observed by solids stratification and sedimentation. The tests will be conducted in a modification of the existing M1 test loop equipment previously used to address pipeline plugging issues during the transport of slurries in the Waste Treatment Plant (Poloski et al. 2009a, b). Test results will support design of a waste certification loop to be installed in the tank farms.

Section 1.1 describes the background associated with this project. Section 1.2 presents the justification for testing. Section 1.3 lists the objectives for this work. Section 1.4 defines the work scope. Section 1.5 describes quality assurance requirements. Section 1.6 lists success criteria.

\subsection{Background}

The delivery of waste to the WTP is governed by specific Waste Acceptance Criteria (WAC) that must be certified as acceptable before any waste can be delivered to the WTP. ICD 19 - Interface Control Document for Waste Feed (Hall 2008) identifies the WTP WAC. Some of the specific waste acceptance criteria are related to the waste feed physical and rheological properties that are not easily measured with a small sample in an analytical laboratory environment. Critical velocity for solids suspension and particle size distribution (PSD) are two of the parameters that are important to slurry transport, and the ability to detect the onset of stratification and critical suspension velocity is of primary interest to this strategy. The tank farms baseline planning includes a certification test loop that will be integrated with the WTP feed delivery systems and will allow real time measurement of the waste feed rheological properties while waste is being circulated through the transfer piping and back to the original source tank. Once rheological and other WAC properties are shown to meet the WAC, the feed will be routed to the WTP receipt tank for further treatment.

The current concept includes a modularized certification test loop that can be integrated into the tank farms feed delivery system with minimal intrusion and footprint. The goal is to develop a certification test loop configuration that uses a minimum of space, instrumentation, and operational interfaces.

The concept to evaluate the feasibility of the certification loop is to modify existing M1 test loop equipment (Poloski et al 2009a, b) to test the anticipated spectrum of WTP feed slurries using representative waste simulants. Test results from the loop will be used to determine appropriate system physical constraints allowing for the effective design of a prototype representative of typical tank farm deployment scenarios.

\subsection{Test Justification}

This evaluation is necessary to identify and select instrumentation and their operating requirements and specify installation requirements for characterizing DST waste transfers in real time via an online 
characterization loop prior to and during waste transfer to the WTP. The main requirement of the certification loop is to demonstrate that the waste feed transferred to the Waste Treatment Plant (WTP) is in compliance with selected properties defined in the WTP waste acceptance criteria: ICD 19 - Interface Control Document for Waste Feed (Hall 2008). At this time, the certification flow loop operation is limited to the requirement that waste slurries exhibit a critical velocity slower than $4 \mathrm{ft} / \mathrm{sec}$ in a three inch pipe.

\subsection{Objectives}

The objectives of this work are to:

- Evaluate performance of three candidate instruments to detect the onset of critical velocity via laboratory testing at full-scale flow conditions (full-scale pipe size and flow rate) using simulated waste materials and

- Define installation and operational requirements for the instrumentation in support of field deployment.

Tests are designed to identify the most appropriate instrumentation, physical configuration, and dimensional limitations that must be incorporated in a certification flow loop design to ensure reliable determination of conformance with the WTP acceptance specification based on critical velocity.

\subsection{Scope}

The work scope for the project includes:

- Developing and implementing a testing strategy to evaluate instrumentation for characterizing DST waste transfers in real time using an online certification loop (Meyer et al 2009b)

- Recommending instrumentation to detect high-level waste (HLW) slurry critical velocity in real time (Meyer et al 2009b)

- Specifying simulants to be used to evaluate instrumentation performance

- Developing the certification loop and instrumentation

- Evaluating the instrumentation performance for a variety of waste simulants

- Selecting appropriate instrumentation for field deployment based on test results, and

- Recommending a path forward based on testing results.

The test plan is limited to real-time determination of the onset of stratification and critical velocity during evaluation of the following instrumentation: pulse-echo ultrasound, ultrasonic attenuation, and ultrasonic Doppler velocimetry. Baseline performance data will be obtained based on use of differential pressure measurement and visual observation of the onset of sedimentation and critical velocity in the clear test section. 


\subsection{Quality Assurance Requirements}

No specific quality standards were required by the client. As such, normal PNNL quality procedures will be followed.

PNNL will operate in accordance with the U.S. Department of Energy (DOE) Prime Contract DE-AC0576RL01830 and the applicable Memorandum of Agreement (MOA) with Pacific Northwest National Laboratory (PNNL) for this scope of work. The terms and conditions of that Prime Contract, including all laws, regulations and DOE Orders are fully incorporated into this Statement of Work.

Under its prime contract, PNNL's QA Program implements DOE Order 414.1C, Quality Assurance, and 10 CFR 830, Nuclear Safety Management, Subpart A, Quality Assurance Requirements. PNNL has adopted NQA-1-2000 as its single consensus standard for implementation of QA requirements. A graded approach is applied to quality in accordance with NQA-1 Subpart 4.2, Guidance for Graded Application of Quality Assurance for Nuclear-Related Research and Development. PNNL's standards-based management system "How Do I?” (HDI) is its web-based system for communicating the QA Program requirements through Laboratory-wide procedures or subject areas. All work at PNNL is subject to the applicable requirements of HDI.

\subsection{Success Criteria}

The success criteria are based on the objectives listed in Section 1.3. The success criteria include:

- Completion of testing to evaluate instrument performance to detect the onset of critical velocity via laboratory testing at full-scale flow conditions (full-scale pipe size and flow rate) using simulated waste materials

- Collection of sufficient data to correlate instrument signals to observed critical velocity conditions

- Development of installation and operational requirements for the instrumentation in support of field deployment. 



\subsection{Test Facility}

The Washington River Protection Solutions (WRPS) Certification Flow Loop will be derived directly from the existing Hanford WTP M1 series initiative test loop constructed for Bechtel within PNNL's Process Development Laboratory - East (PDLE) facility. This approach minimizes construction expense and shortens the period of construction, development, and performance of testing for an initiative closely similar to M1.

The M1 series initiative test loop consists of approximately $200 \mathrm{ft}$ of 3-in. diameter Schedule 40 pipe with a pump capable of slurry velocities up to $12 \mathrm{ft} / \mathrm{sec}$. This loop is instrumented with Coriolis flow meters, in-situ particle size analysis, as well as differential pressure transducers to determine pressure drop as a function of flow velocity. Electrical resistance tomography used during M1 is also available for the purpose of flow characterization and visualization, but will not be used during this test campaign. During M1 testing (Poloski et al 2009a, b) the system was used successfully to investigate three major issues: 1) slurry transport settling velocities of particles in turbulent and laminar flow regimes with Newtonian and non-Newtonian flow features, characteristics and effects; 2) verification of adequate design velocities for complex piping geometries; and 3) development of pipeline flushing techniques.

Maintaining particle inventory per volume is critical during these tests, and it is important that the test section is the initial location for particle deposition during testing. Additionally, it is important to minimize the overall slurry test volume without adversely affecting testing results and determination. These criteria have led to the development of two loop configurations to accommodate two classes of simulant: 1) simulants where slurry yield stress is low ( 0 Pa) and no specific rheological tailoring is required to occur between tests, i.e., the slurry carrier fluid properties are similar to water, and 2) simulants involving slurries with higher yield stresses ( $>0 \mathrm{~Pa}$ ). These loop configurations will be referred to as the "Short-Circuit Loop" for conducting tests where slurry yield stress is low ( 0 Pa) and the "Standard Loop" for conducting tests in situations involving slurries with higher yield stresses ( $>0 \mathrm{~Pa})$. These loops are described in Section 2.1 and Section 2.2, respectively. Design drawings and details for the loops are shown in Figure 2.1, Figure 2.2, Figure 2.3 and Figure 2.4. Both configurations will incorporate identical test sections and auxiliary instrumentation. The test section is described in Section 2.3. System functions and requirements are listed in Section 2.4.

\subsection{Short-Circuit Loop Configuration}

The purpose of the Short-Circuit loop configuration is to maintain precise simulant particle inventory and to reduce the duration of testing time required to achieve steady state at particular evaluation velocities. The Short-Circuit loop will be used for tests with relatively fast-settling solids in Newtonian fluids. To minimize and carefully control the inventory of solids, the mixing tank is eliminated from the Short-Circuit loop. To promote preferential particle settling in the instrument test section instead of elsewhere in the loop, it is important to maintain fluid velocities higher in the interconnecting piping than in the instrument test section. That condition is met by reducing the diameter of the piping to a size slightly smaller than the piping used for the test section, which will result in a higher fluid velocity in the smaller diameter piping. The Short-Circuit Loop volume is 40 gallons. Solids and liquid will be added to the Short-Circuit Loop via the hopper shown in Figure 2.1 and in Figure 2.2, detail 2. 



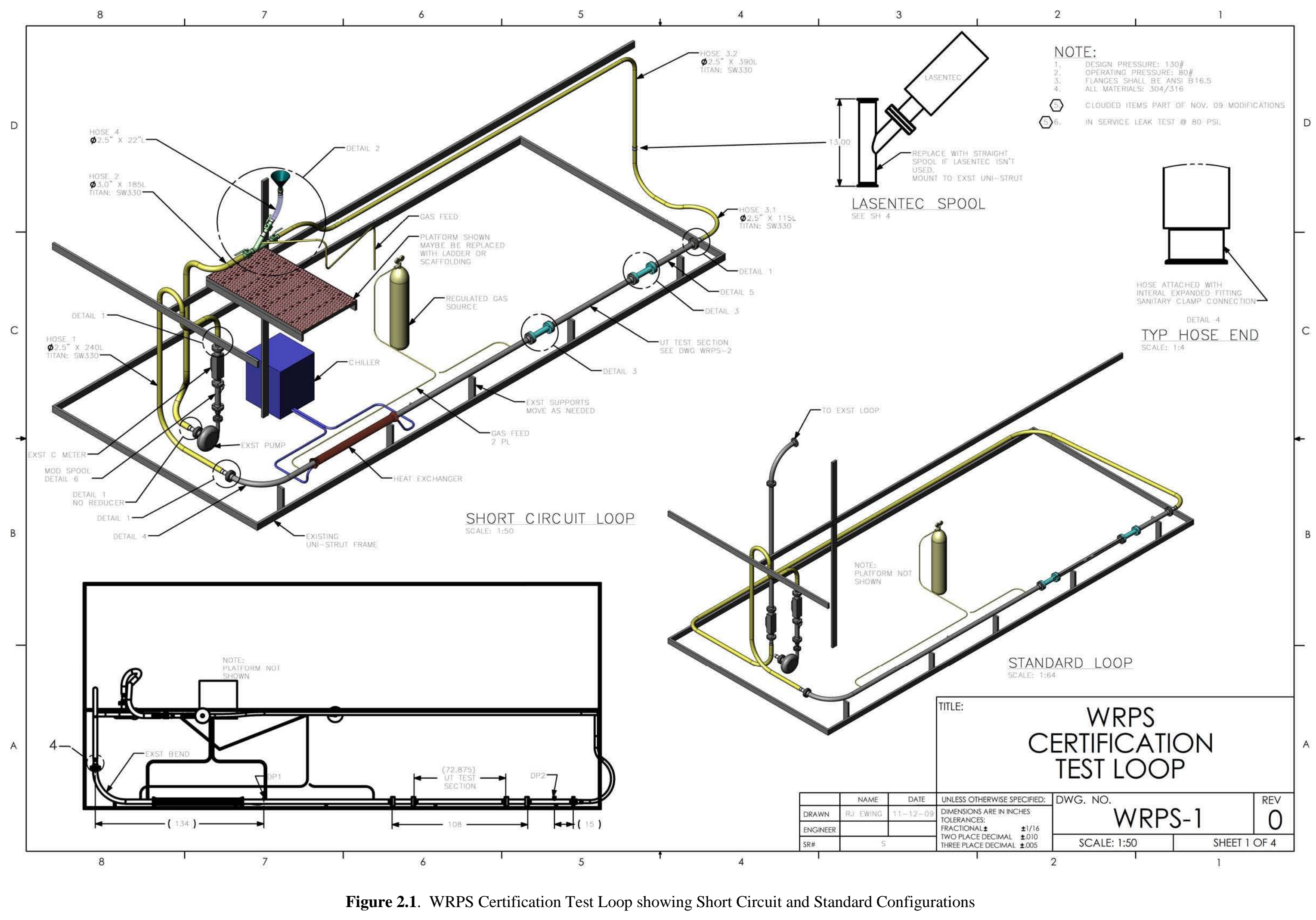





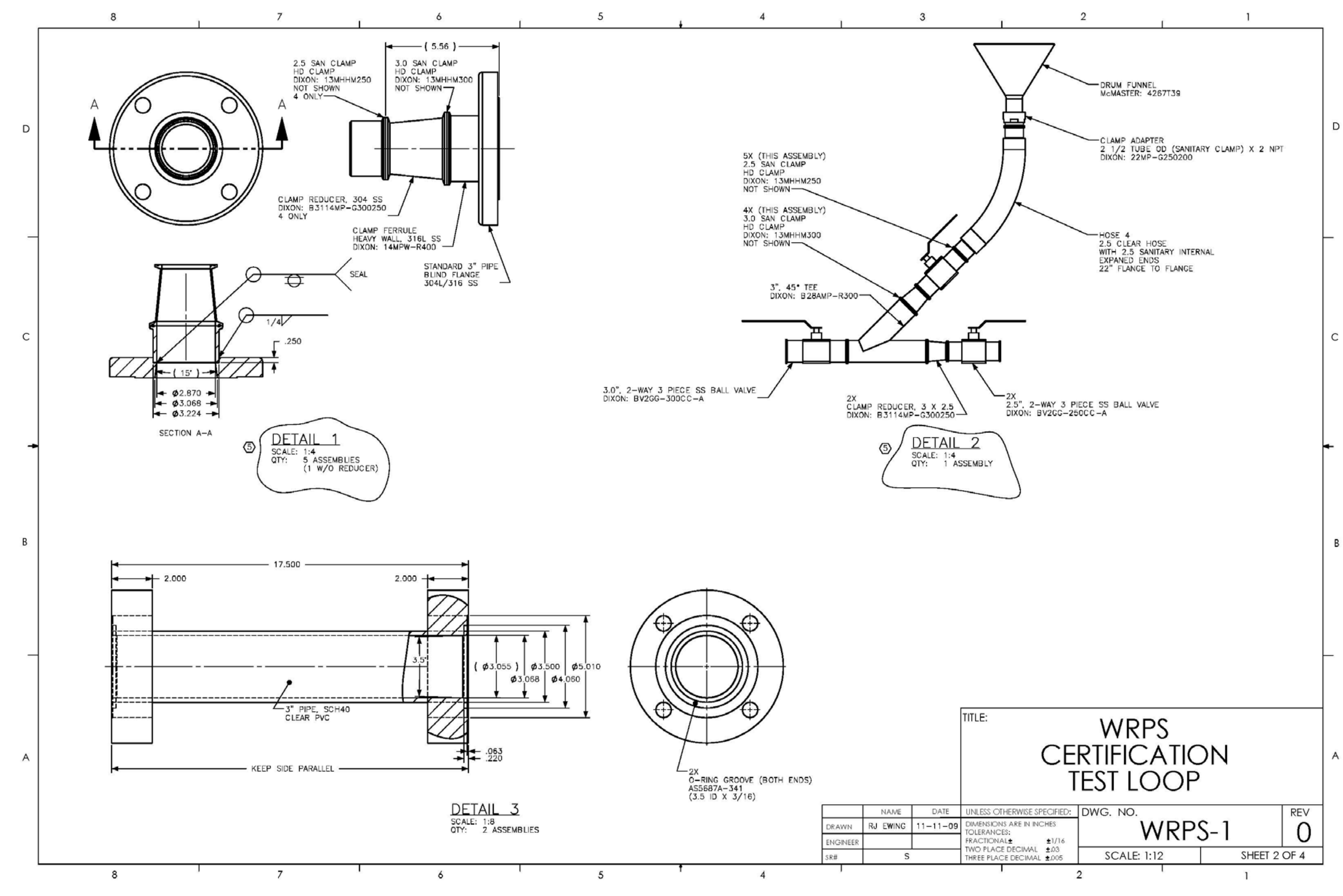

Figure 2.2. WRPS Certification Test Loop Details 1, 2, and 3 



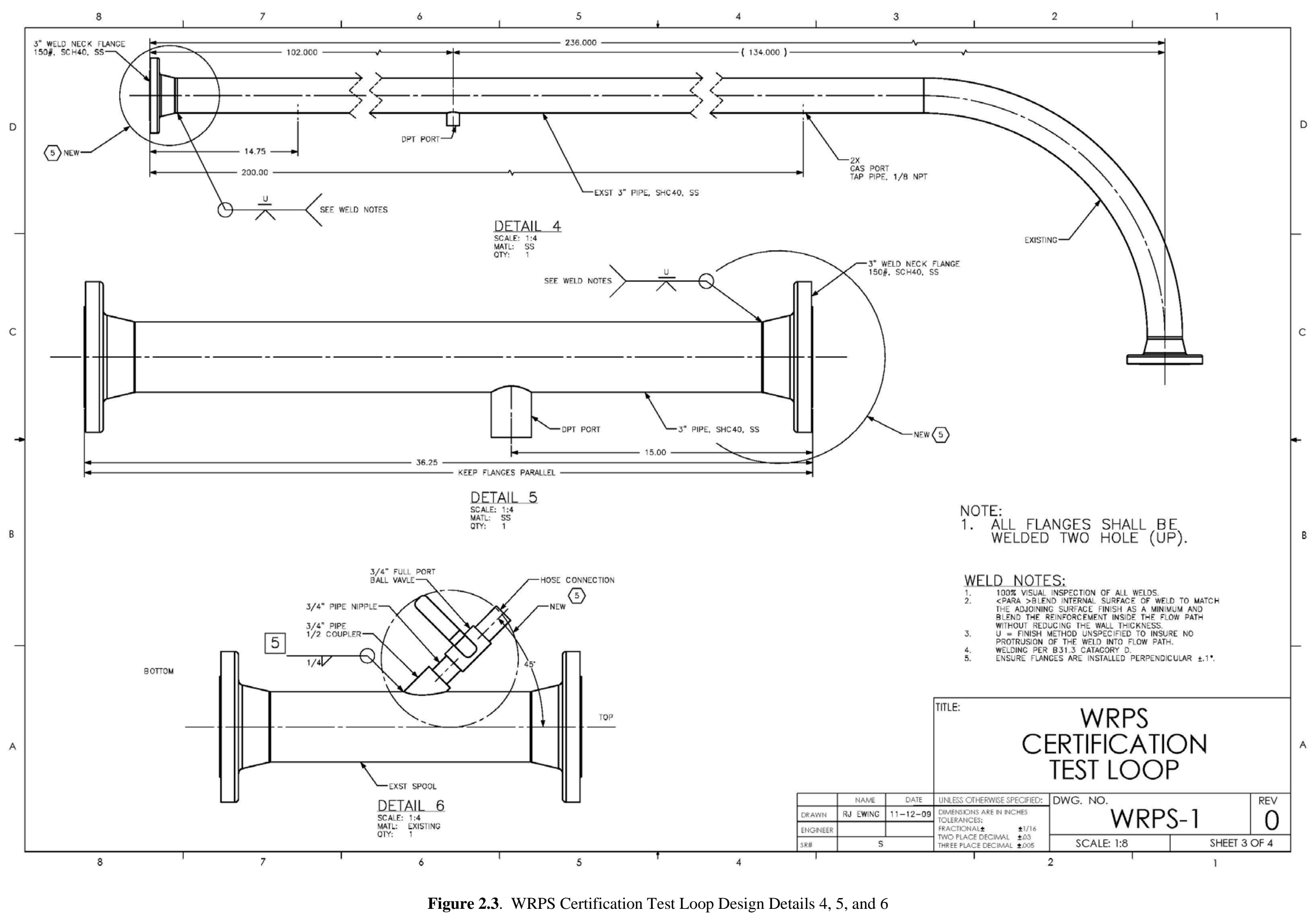





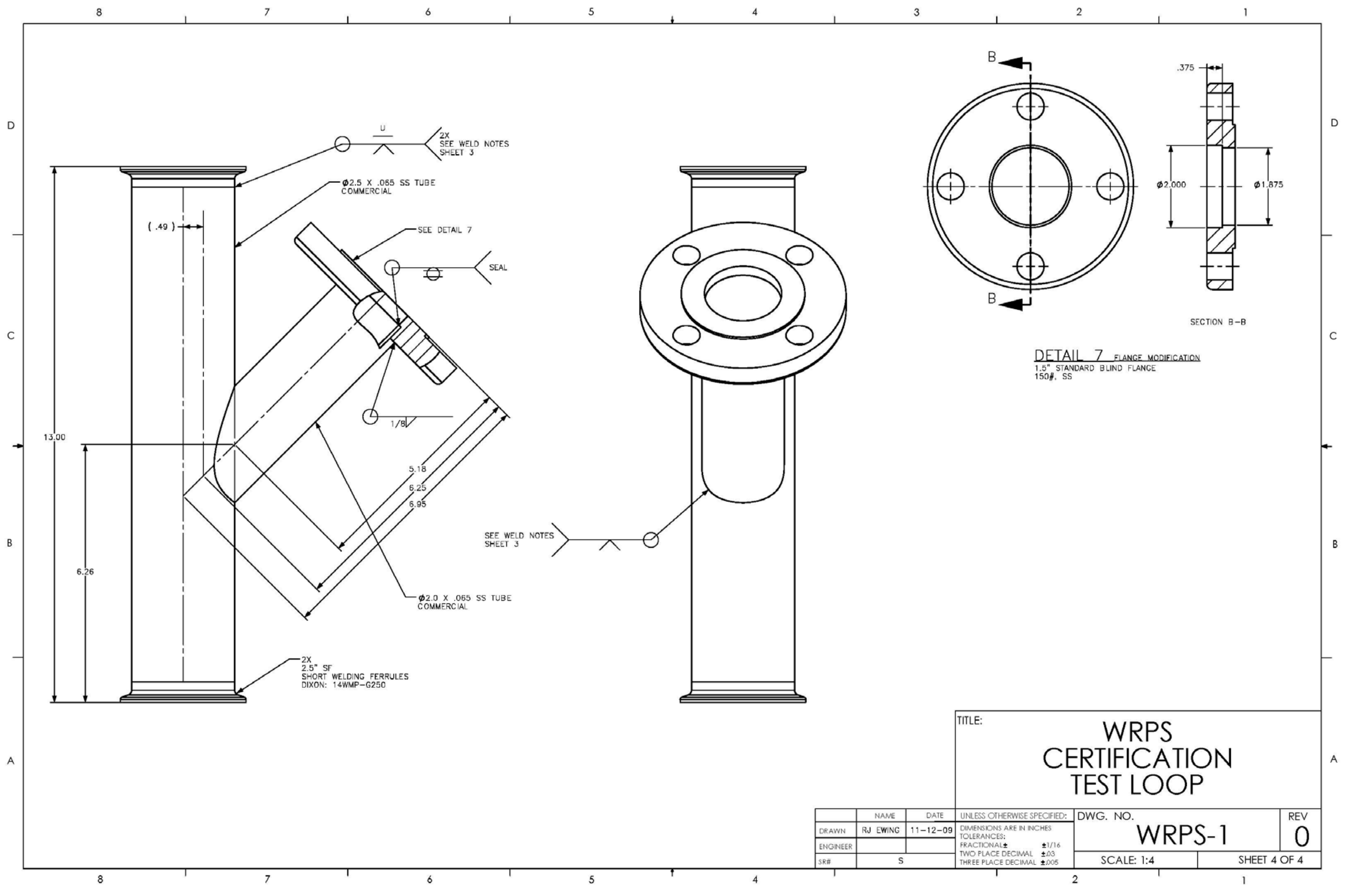

Figure 2.4. WRPS Certification Test Loop Design Details for Lasentec ${ }^{\mathrm{TM}}$ Sensor Mount 



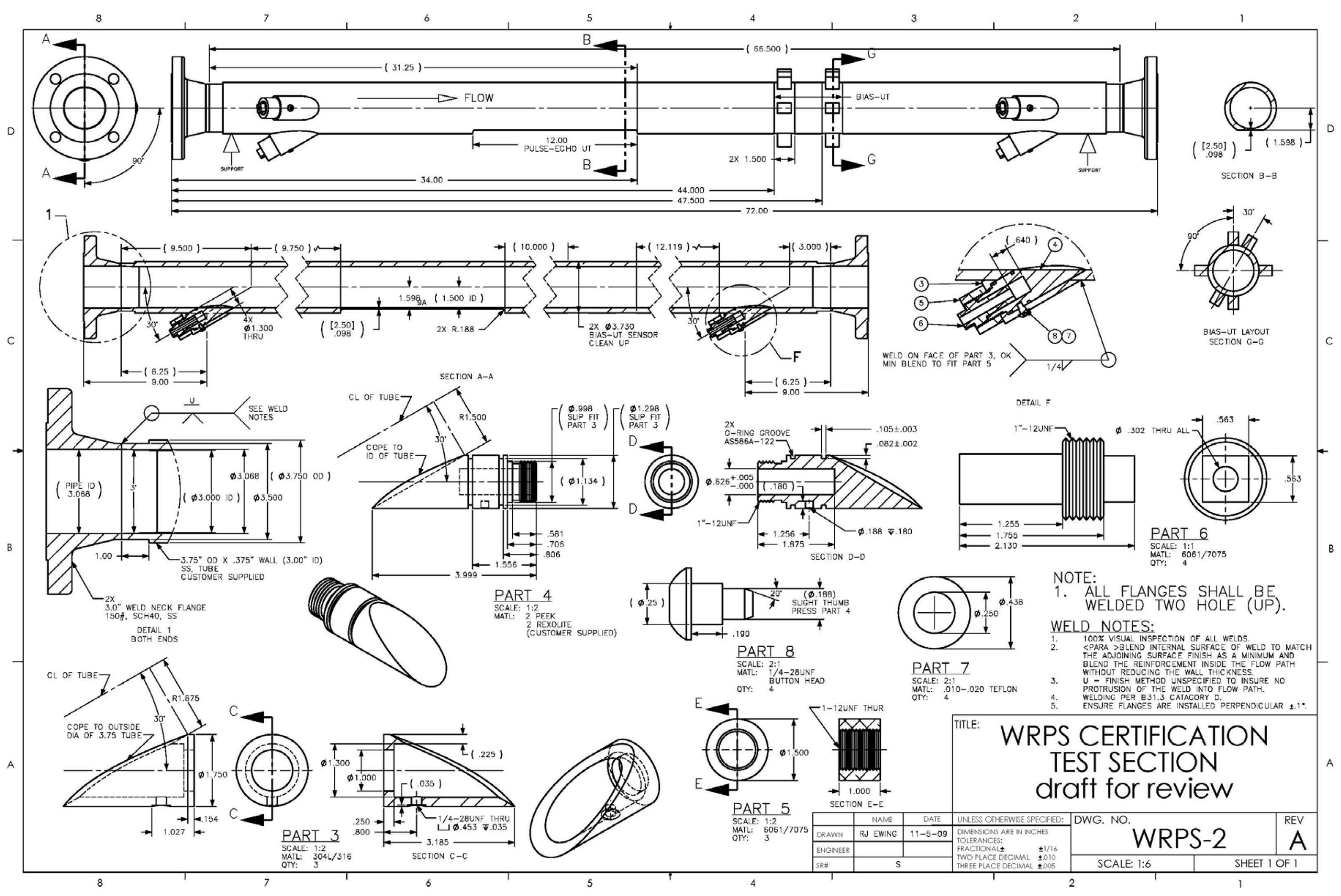

Figure 2.5. WRPS Certification Test Section 



\subsection{Standard Loop Configuration}

Although the implementation of the short circuit loop for Newtonian simulants is straight forward, there is some concern about the ease of using the short circuit configuration with the non-Newtonian simulants (involving slurries with higher yield stresses i.e., $>0 \mathrm{~Pa}$ ). The primary concern here is whether the rheology can be adequately adjusted in the short circuit loop without requiring frequent depressurization and simulant additions. This is because the rheology of the clay simulant depends upon several factors such as the concentration of the clay, batch of clay, its hydration, and the concentration of the rheology modifier.

Prior to the start of the testing with non-Newtonian simulants, an attempt will be made to determine whether the short circuit loop can be used to test with these simulants. In the event that achieving the correct rheology becomes too cumbersome, the Standard Loop configuration will be used for further the evaluation sensors using non-Newtonian simulants. This loop includes the existing mixing tank, flush tank, and capture tank; however, the original M1 test section will be replaced with smaller-diameter hose. The benefit of this configuration is to maintain rheological consistency over the duration of testing. Having a larger volume of simulant reduces the effect of periodic flushing of differential pressure ports which causes dilution of the simulant. The distinctive differences between the Standard and Short-Circuit Slurry Certification Flow Loop configurations are that the mixing vessel and overall pipe holdup has been left intact instead of reducing the simulant circulation volume.

\subsection{Test Section}

The test section location, shown in Figure 2.1, houses the specially constructed spool pieces for the ultrasonic instrumentation. Clear acrylic viewing ports are located on either ends of the test section. Each viewing port will provide $\sim 1 \mathrm{ft}$ of clear acrylic pipe to permit observation of the slurry and the onset of sedimentation and confirmation of critical velocity condition. Details of the test section are shown in Figure 2.5.

\subsection{System Functions and Requirements}

Major subsystems for the WRPS Certification Loop are identified in Table 2.1. System requirements are identified along with a corresponding design specification to meet these functions and requirements. 
Table 2.1. Major Subsystems for the WRPS Certification Loop

\begin{tabular}{|c|c|c|}
\hline System & Functions and Requirements & Specification \\
\hline \multirow[t]{2}{*}{ General } & $\begin{array}{l}\text { 1) Modifications to the pipe loop will } \\
\text { accommodate testing of instruments selected } \\
\text { for potential use in certifying acceptability of } \\
\text { waste transfers to WTP. }\end{array}$ & $\begin{array}{l}\text { 1) All modifications were designed with safety and } \\
\text { ease of access as a priority. }\end{array}$ \\
\hline & $\begin{array}{l}\text { 2) The system design will be consistent with } \\
\text { previous (M1) material specifications. All } \\
\text { changes will be performed such that the loop } \\
\text { can be easily restored to the original } \\
\text { configuration. }\end{array}$ & $\begin{array}{l}\text { 2) Hazardous chemicals are not included in the test } \\
\text { plans; however, the system was designed for } \\
\text { potential use of acids and caustics. Safety reviews } \\
\text { were completed. }\end{array}$ \\
\hline \multirow[t]{3}{*}{$\begin{array}{l}\text { Mixing } \\
\text { Vessel }\end{array}$} & $\begin{array}{l}\text { 1) System must be designed to adequately } \\
\text { suspend up to a } 20 \text { vol\% of a slurry of } 500 \\
\mu \mathrm{m} \text { particles of iron oxide at a density of } 5 \mathrm{~g} / \mathrm{l} \\
\text { in water. }\end{array}$ & $\begin{array}{l}\text { 1) Standard solids suspension system with capacity } \\
\text { rated mechanical agitator, dish, elliptical or conical } \\
\text { bottom, and four-baffle geometry is employed. }\end{array}$ \\
\hline & $\begin{array}{l}\text { 2) Mixing vessel must have at least } 3 \text { times } \\
\text { the working volume of the flow loop. }\end{array}$ & $\begin{array}{l}\text { 2) Vessel volume of } 450 \text { gallons exceeds } 3 \text { volumes } \\
\text { equivalent to } 171 \text { feet of } 3 \text { in. ID pipe in current } \\
\text { configuration (approximately } 60 \text { gallons while in } \\
\text { Standard Configuration). }\end{array}$ \\
\hline & $\begin{array}{l}\text { 3) System must be equipped with heat } \\
\text { rejection capability to maintain isothermal } \\
\text { conditions during testing. }\end{array}$ & $\begin{array}{l}\text { 3) Mixing vessel is jacketed for temperature control } \\
\text { and has an appropriately sized chiller. Short-Circuit } \\
\text { Loop Configuration employs a pipe-in-pipe heat } \\
\text { exchanger and uses the same chiller. }\end{array}$ \\
\hline \multirow[t]{3}{*}{ Pump } & $\begin{array}{l}\text { 1) Must be compatible with slurries to } \\
\text { minimize attrition. }\end{array}$ & $\begin{array}{l}\text { 1) Centrifugal slurry pump with } 0.9 \text { in. } x 1.2 \text { in. } \\
\text { vein passages (GIW 3x2, } 15 \mathrm{HP} \text { ) in place. }\end{array}$ \\
\hline & $\begin{array}{l}\text { 2) Must be capable of developing line } \\
\text { velocities ranging from } 0.5 \mathrm{ft} / \mathrm{s} \text { to } 10 \mathrm{ft} / \mathrm{s} \\
\text { handling fluids ranging from water to a } \\
\text { Bingham plastic fluid of } 30 \mathrm{cP}, 30 \mathrm{~Pa}, 2 \mathrm{SG}\end{array}$ & $\begin{array}{l}\text { 2) Pump as specified for } 220+\text { gpm at nominal } \\
\text { operation to achieve adequate velocities in } 3 \text { in. ID } \\
\text { test section(s). }\end{array}$ \\
\hline & 3) Pulsations must be minimized. & $\begin{array}{l}\text { 3) Installation of a pulsation dampener was not } \\
\text { required }\end{array}$ \\
\hline
\end{tabular}


Table 2.1. (contd)

\begin{tabular}{ll}
\hline System & \multicolumn{1}{c}{ Functions and Requirements } \\
\hline Piping & $\begin{array}{l}\text { 1) Peak pressure control will be used to limit } \\
\text { high pressures in piping, hosing, and } \\
\text { transparent test section during flushing } \\
\text { operations. }\end{array}$ \\
\\
2) Must be chemically compatible with \\
simulants and flush solutions. \\
3) Piping will be reconfigurable for either a \\
"Standard" system that includes a mixing \\
vessel in-line, or a "Short Circuit" system that \\
bypas the mixing vessel.
\end{tabular}

4) Must be flushable regardless of whether it is configured as "Standard" or "Short-

Circuit” layout.

5) System must be equipped with a cooling jacket or coils to maintain isothermal conditions during the test.

6) A smooth flow path throughout the loop shall be provided as much as practicable so as to minimize simulant loss and the introduction of artificial flow features/characteristics (especially in the vicinity of the test section).

7) A maximum of 2.5 in. D piping or hose shall be used in sections outside of critical test regions. Transitions between ID changes shall be performed so as to minimize pressure

5) The mixing vessel jacket provides temperature control during operation in Standard Loop configuration. A custom built heat exchanger consisting of $3 / 4^{\text {th }}$ inch copper tubes $\sim 5 \mathrm{ft}$ in length glued to the pipe (using conductive epoxy) was installed in the loop to control the loop temperature in the Short Circuit configuration.

6) All welding was performed to minimize penetration within the pipe ID (i.e., partial penetration groove welds). All hose /fitting combinations were selected to minimize trip edges and discontinuities using internally expanded sanitary fittings. All flanged/gasketed connections were custom specified/assembled to eliminate gaps or path protrusions using raised-face weld-neck flanges with custom cut ID matched gaskets.

7) Standard pipe reducers were used in convergent locations. A maximum full angle of 7 degrees was 
Table 2.1. (contd)

\begin{tabular}{|c|c|c|}
\hline System & Functions and Requirements & Specification \\
\hline & \multirow[t]{2}{*}{$\begin{array}{l}\text { drop and simulant settling as much as } \\
\text { possible. }\end{array}$} & applied to divergent locations. \\
\hline & & $\begin{array}{l}\text { The Short Circuit slurry pump inlet hose was } \\
\text { expanded to } 3 \text { in. to reduce piping losses incurred } \\
\text { just prior to entering the pump housing. Simulant is } \\
\text { not anticipated to settle prematurely in the leg } \\
\text { because it is predominantly vertical in nature. }\end{array}$ \\
\hline $\begin{array}{l}\text { Flush } \\
\text { System }\end{array}$ & $\begin{array}{l}\text { 1) Must be capable of freeing up any possible } \\
\text { plugs as well as evacuating the system of } \\
\text { simulant without exceeding safe operating } \\
\text { limits of loop, transparent sections, and } \\
\text { instrumentation within test section. }\end{array}$ & $\begin{array}{l}\text { 1) Flush system pressures are administratively } \\
\text { limited to that of the transparent sections to protect } \\
\text { them from possible over-pressurization damage. } \\
\text { The burst pressure for the transparent section at 20C } \\
\text { is } 120 \# \text {. This flush pressure is adequate for } \\
\text { removing material from the WRPS Certification test } \\
\text { loop via flushing. }\end{array}$ \\
\hline \multirow[t]{4}{*}{$\begin{array}{l}\text { System } \\
\text { Controls }\end{array}$} & $\begin{array}{l}\text { 1) Mass flow rate shall be monitored to a } \\
\text { minimum accuracy of }+/-0.55 \% \text {, variance } \\
\text { from actual. }\end{array}$ & $\begin{array}{l}\text { 1) Existing Coriolis flow meters is used for mass } \\
\text { flowrate indication. }\end{array}$ \\
\hline & $\begin{array}{l}\text { 2) Flow rate shall be controlled to maintain a } \\
\text { manually selected setpoint. }\end{array}$ & $\begin{array}{l}\text { 2) A feed-back loop from the flowmeter is used to } \\
\text { adjust a variable frequency drive on the pump to } \\
\text { control flowrate. }\end{array}$ \\
\hline & $\begin{array}{l}\text { 3) Fluid temperature must be monitored and } \\
\text { controlled. }\end{array}$ & $\begin{array}{l}\text { 3) Fluid temperature control exists during operation } \\
\text { in Standard Loop configuration via the mixing } \\
\text { vessel jacket and in Short-Circuit Loop } \\
\text { configuration via the heat exchanger. }\end{array}$ \\
\hline & $\begin{array}{l}\text { 4) Data acquisition will be automated, and } \\
\text { will be tailored to the instruments being } \\
\text { evaluated. }\end{array}$ & $\begin{array}{l}\text { 4) The ultrasonic instruments are stand-alone } \\
\text { systems that only require a time stamp. An existing } \\
\text { DASYLab system or Omega data collection system } \\
\text { is available for system data acquisition }\end{array}$ \\
\hline \multirow[t]{3}{*}{$\begin{array}{l}\text { Instrument } \\
\text { Test Section }\end{array}$} & $\begin{array}{l}\text { 1) Candidate instruments shall be mounted in } \\
\text { a straight and horizontal } 3 \text { in. Schedule } 40 \\
\text { stainless steel pipe with sufficient straight } \\
\text { pipe sections to assure fully developed } \\
\text { velocity profiles. }\end{array}$ & $\begin{array}{l}\text { 1) The candidate instruments were placed at least } \\
40 \text { pipe diameters of straight pipe after and } 5 \text { pipe } \\
\text { diameters prior to flow disturbances induced by } \\
\text { joining and loop construction features (based on } \\
\text { assumed turbulent flow conditions). }\end{array}$ \\
\hline & $\begin{array}{l}\text { 2) Instrumented test section will include at } \\
\text { least one differential pressure transducer } \\
\text { section and two transparent sections. }\end{array}$ & $\begin{array}{l}\text { 2) The existing Rosemount differential pressure } \\
\text { transducers are used to quantify pressure drop } \\
\text { across the test section. }\end{array}$ \\
\hline & $\begin{array}{l}\text { 3) Instrumented test section will include two } \\
\text { transparent sections; one installed before the } \\
\text { first candidate instrument, and one after the } \\
\text { last instrument. }\end{array}$ & $\begin{array}{l}\text { 3) Transparent pipe sections are } \sim 12 \text { in. long, } \\
\text { fabricated with internal diameters identical to the } \\
\text { mating } 3 \text { in. Schedule } 40 \text { stainless steel pipe. } \\
\text { Material was selected with high optical } \\
\text { transmission, minimal distortion, and compatible } \\
\text { with acidic and caustic fluids. The sections are } \\
\text { rated for } 1.5 \text { times the maximum possible generated } \\
\text { pressure. Transparent sections were installed at the } \\
\text { beginning and end of the test section such that }\end{array}$ \\
\hline
\end{tabular}


Table 2.1. (contd)

\begin{tabular}{lll}
\hline System & \multicolumn{1}{c}{ Functions and Requirements } & \multicolumn{1}{c}{ Specification } \\
\hline & $\begin{array}{l}\text { visually observable differences in flow } \\
\text { characteristics or flow anomalies within the length } \\
\text { of the test section, if any, can be detected. }\end{array}$ \\
$\begin{array}{ll}\text { 4) Candidate instruments will be selected to } \\
\text { measure or detect critical velocity, PSD, } \\
\text { solids concentration, and rheological } \\
\text { parameters. }\end{array}$ & by WRS. \\
\hline Sampler & $\begin{array}{l}\text { 1) A sampler or sampling system shall be capability was removed } \\
\text { utilized that most accurately samples the in- } \\
\text { process slurry while minimizing adverse } \\
\text { impacts to flow and slurry composition as } \\
\text { well as minimizing possible bias. }\end{array}$ & $\begin{array}{l}\text { 1) The mixing vessel grab sample sampling method } \\
\text { employed during WTP M1 will be used to obtain } \\
\text { samples from the mixing vessel. The composition } \\
\text { within the Short-Circuit loop configuration can be } \\
\text { readily determined via calculation based on design. }\end{array}$ \\
\hline
\end{tabular}





\subsection{Test Measurements}

The goal of the certification flow loop is to provide real-time, in-situ characterization of specific properties of the waste slurry to be transported to the WTP. The goal of the testing is to evaluate instrument performance over the entire range of conditions that could affect instrument performance. That will necessarily include Newtonian and non-Newtonian flow regimes, as indicated in the test matrix presented in Section 4. This section describes the reference methods and instrumentation to be included in the flow loop and the instrumentation whose performance is to be evaluated. Reference methods and instruments for determining critical velocity are described in 3.1. Ultrasonic technologies being evaluated for detection of critical velocity are described in Section 3.2. Additional supporting instrumentation is described in Section 3.3.

\subsection{Reference Methods for Measuring or Detecting Critical Velocity}

The pipeline transport of solids suspended in a carrier liquid is considered "critical” when the flow velocity is just at the point where solids are not fully suspended. The behavior of the solids at this velocity will depend on the specific properties of the solids and the carrier fluid and may exhibit conditions ranging from a solids concentration gradient, to "saltation”, to "sliding bed", or even a stationary layer of solids. In any case, the critical velocity represents an unstable flow condition that could lead to incipient pipeline plugging with only small changes in flow rate, or solids concentration, or rheology. It is for that reason that waste transfers must be confirmed to exhibit a critical velocity lower than the requirement of $4.0 \mathrm{ft} / \mathrm{s}$ flow velocity as required by ICD 19 (Hall 2008).

Each of the possible phenomena indicating critical velocity noted above offers an opportunity to detect the critical velocity condition. These include:

- a vertical solids concentration gradient

- a change in the solid particle size distribution in suspension

- saltation

- sliding bed

- stationary layer of solids.

The following subsections describe specific instrumentation and observations to be used as reference instrumentation to detect or quantify these conditions.

\subsubsection{Resistance to Flow as Indicated by Differential Pressure}

Pipeline pressure drop characteristics can be used to infer information about the critical velocity. Differential pressure between two points separated by a known length in a horizontal pipeline can be compared using sensitive devices such as differential-pressure transducers.

For a well-suspended slurry, the differential pressure in a segment of pipe generally decreases as flow velocity decreases. When the flow velocity is lowered to approach the critical velocity from a higher velocity, the differential pressure will decrease less as the solids become stratified and ultimately increase 
as the solids settle and accumulate on the pipe floor. Changes in differential pressure may also result from changes in rheological properties of a slurry, so there is a need to know enough about the system to understand the cause-effect relationship. The distribution of solids in the flow loop will vary widely as the velocity is varied. This solids distribution variation results in pressure drop variations with velocity resulting in a "J"- curve response as illustrated in Figure 3.1. The anticipated ranges of application for each ultrasonic sensing technique are added to the figure. At very high velocity the solids are well suspended and distributed uniformly in the vertical plane. That is in the flow no vertical gradients in concentration or composition exist. At low velocities a stationary solids bed forms and plugging ensues. The entire range of behavior can be considered in terms of three velocities, $\mathrm{U}_{1}, \mathrm{U}_{2}$, and $\mathrm{U}_{3}$. For velocity $\mathrm{U}>\mathrm{U}_{1}$ solids are well distributed vertically. Hence $\mathrm{U}_{1}$ is defined as the velocity below which solids vertical stratification occurs. $U_{2}$ is defined as the sedimentation velocity at which a sliding bed of solids forms on the pipe floor. This is commonly referred to as the critical velocity for sedimentation and generally coincides with the minimum point on the "J" curve. $\mathrm{U}_{3}$ is defined as the velocity at which particles on the floor become stationary. For $\mathrm{U} \leq \mathrm{U}_{3}$, solids will build up leading essentially to the occurrence of pipeline plugging. The critical velocity for the purpose of the certification loop is somewhat loosely defined. Hence by varying the flow-loop velocity and monitoring pressure drop, the critical velocity can in principle be inferred.

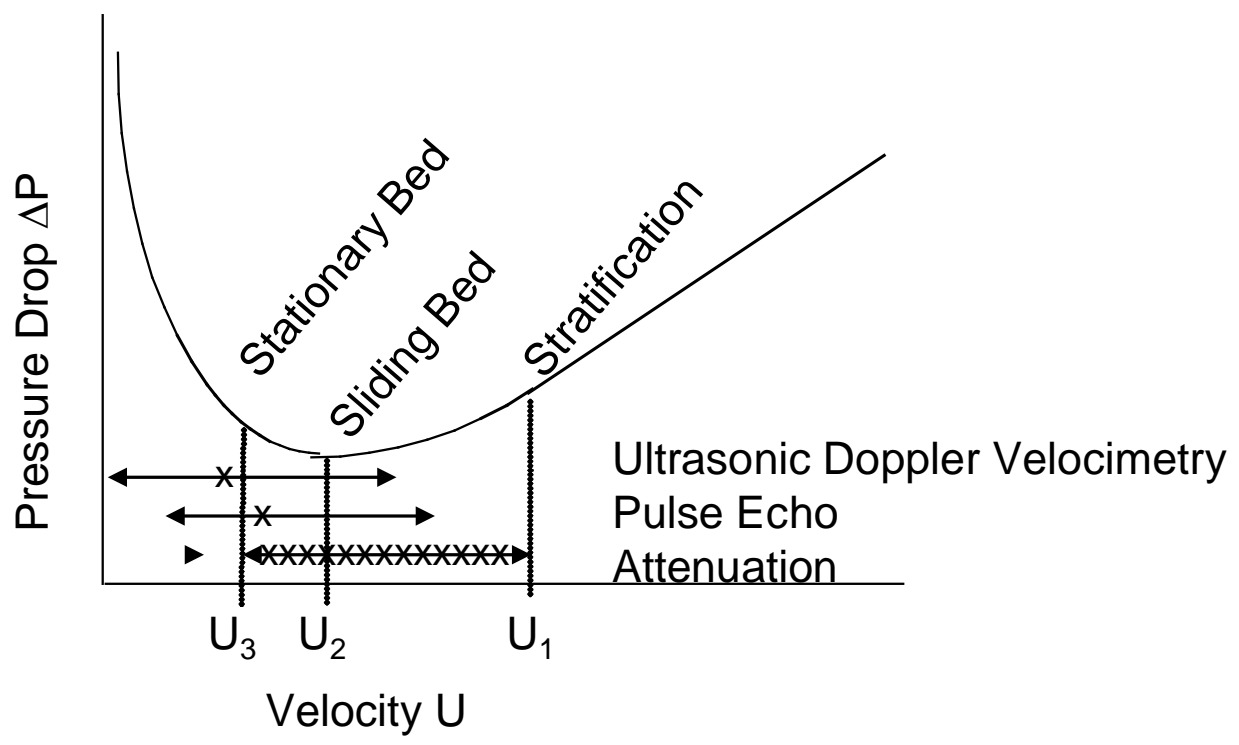

Figure 3.1. Illustration of Regions of Solids Behavior in Terms of Pressure Drop in a Section of Pipe. $\mathrm{x}$ indicates the detection velocity for each instrument.

Rosemount 1151 differential-pressure transducers were used during the M1 deposition velocity studies (Poloski et al 2009a, b). A similar configuration is used in the critical velocity flow loop test section. The pressure transducers are connected to the flow loop through open horizontal weldolet connectors. The open design of the ports was selected over diaphragm systems to allow for greater pressure sensitivity. Based on successful use during M1 testing when sediment was expected to fill these ports during operation, a differential-pressure port purge system was installed. This system allowed the differential-pressure transducers to be isolated from the flow loop. The differential-pressure ports were then cleaned by briefly flushing lines with high pressure water. This purge process will be implemented as needed throughout testing. Two transducers with differing pressure measurement ranges were 
connected to a pair of weldolet ports. This allowed for a broad range of pressure measurements to be conducted.

\subsubsection{Visual and Camera Imaging}

Installation of a clear spoolpiece at each end of the test section permits visual and optical observation of the flow in the pipe loop. As solids are deposited on the pipe floor, the velocity near the floor decreases (indicating a sliding bed onset at velocity $\mathrm{U}_{2}$ ) or may stop (indicating a stagnant layer at velocity $\mathrm{U}_{3}$ ). These conditions offer an opportunity for detection by visual or optical techniques that detect or quantify motion.

To complement visual observation, a high-resolution camera was mounted beneath a clear section of pipe. The camera is a Point Grey Research model Grasshopper - GRAS20S4M - monochrome [B/W]. It has a 1624 x 1224 pixel sensor, with each pixel $4.4 \mu \mathrm{m}$ x $4.4 \mu \mathrm{m}$ square. The camera runs at 30 frames/second at full resolution [1600 x 1200 pixels]. The camera lens is a Donder Zoom Module that will provide a FOV (field of view) of $3.2 \mathrm{~mm}$ to $12.8 \mathrm{~mm}$ over the zoom range of the lens.

\subsection{Development Methods for Measuring Critical Velocity}

Three ultrasonic instruments were developed and their ability to detect flow characteristics associated with critical velocity such as $U_{1}, U_{2}$, and $U_{3}$ shown in Figure 3.1 is being evaluated. The instruments are described in the following subsections. Ultrasonic sensors were selected for these measurements because ultrasound signals can interrogate fluids and dense opaque suspensions, penetrate vessel and process piping walls, and are not degraded by process conditions (Bamberger and Greenwood 2004). Ultrasonic sensors provide real-time, in situ measurement or visualization and the sensing systems are compact, rugged, and inexpensive and can be built to withstand exposure to radiation (Bamberger and Greenwood 2001).

\subsubsection{Layer Thickness Detection with Pulse-Echo Ultrasound}

A layer of solids on the bottom of the pipeline, whether moving or not, indicates that the flow rate has dropped below the critical velocity. Detection of a layer of solids on the pipe floor would be a positive indicator that the flow conditions are at or below the critical velocity. One means of detecting a solids layer employs ultrasonic energy in a pulse-echo system.

In this system an ultrasonic transducer is attached to the outside surface of a horizontal section of pipe beneath the pipe. Single-sided access to the measurement location is required. Ultrasonic pulses generated by the transducer penetrate the pipe wall and the fluid contents within the pipe. Ultrasonic backscatter signals from solid particles contained in the fluid are used to detect the presence of settled solids inside the pipe. Ultrasonic measurements are performed at microsecond time scales. Suspended, mobilized solids result in highly modulated ultrasonic backscatter signals with respect to time. Settled solids result in ultrasonic backscatter signals that are not modulated with respect to time. The ultrasonic signals received by the ultrasonic transducer are digitized by a digitizer card and analyzed real-time by a computer algorithm. Signals are generated at a rate of $100 \mathrm{~Hz}$. A set of 10 signals is used by the algorithm to determine if settled solids are present inside the pipe, therefore resulting 10 read-outs per second. The depth of the settled solids layer is determined by measuring the point in time in the 
backscatter signal where the signal becomes modulated. This point represents an interface between a stationary and moving fluid. If the speed of sound through the slurry is known, which can be determined through routine laboratory measurements, the distance from the transducer to the moving interface can be calculated thereby determining the thickness of the settled layer.

The sensors used in this system are mounted externally to the pipe spool piece and do not present any interference to the flow. The ultrasonic transducer selected is a 0.25 in. diameter piezocomposite transducer that operates at $5 \mathrm{MHz}$.

\subsubsection{Concentration Profile Measurement with Ultrasonic Attenuation}

Slurry flowing at or near the critical velocity will exhibit stratification (a solids profile in a horizontal pipe that is more concentrated at the bottom than the top). The ability to detect or even quantify a solids concentration gradient offers the potential to understand how close the flow conditions are to becoming critical. Detecting the presence of a gradient would indicate that the flow is close to critical velocity. If the gradient can be resolved to detect the presence of a layer on the pipe floor, the actual critical velocity can be determined. Ultrasound energy can potentially be used to provide this information by measuring the attenuation of the ultrasound signal as it passes through the slurry.

For a pipeline with flow in the horizontal direction, the sensor was designed to include three pairs of 3/4-in. diameter narrow-band transducers placed on opposite sides of the spoolpiece oriented 1) vertically, 2) horizontally, and 3) at an angle of 30 deg from the vertical. The spoolpiece contains two rings of transducers, one ring of $3.5 \mathrm{MHz}$ transducers and another ring of 2.25 MHz transducers. The transducers

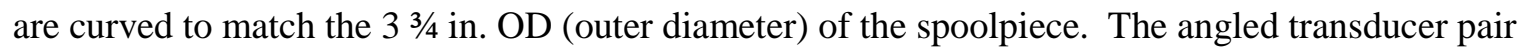
provides additional information about the slurry uniformity and provides a measurement for comparison if a bubble forms along the top of the spoolpiece. Each transducer pair measures the attenuation of the signal through the spoolpiece from the transmit to the receive transducer. If the slurry is uniformly distributed, then the attenuation will be the same for all transducer pairs. If the slurry starts to settle, then the attenuation in the vertical direction will be greater than the attenuation in the horizontal direction. The degree of suspension (DoS) is defined as the ratio of the attenuation in the horizontal direction to that in the vertical direction. DoS is equal to 1 for a well-mixed slurry and DoS is equal to 0 when the slurry is completely settled. By measuring the degree of suspension as a function of the flow velocity, the flow velocity at which DoS deviates from 1 can be determined. This velocity is shown as $U_{1}$ in Figure 3.1. This velocity will be strongly correlated to the critical velocity.

The standard method for measuring the attenuation of ultrasound is to have two transducers in contact with the slurry and separated by a distance, D. One transducer transmits ultrasound into the slurry and, after the ultrasound travels through the slurry, the receive transducer measures the voltage signal, $\mathrm{V}_{\text {slurry }}$. In order to calibrate the system, the same measurement is carried out when the liquid between the two transducers is water, and the voltage, $\mathrm{V}_{\text {water }}$, is measured. A very accurate method for measuring attenuation has been developed by Greenwood et al. (2006), in which multiple reflections through the slurry produce a long path and increase the accuracy of the attenuation measurement. In addition, the method is self-calibrating, ${ }^{1}$ which means that the measurement is not affected by changes in the system electronics.

${ }^{1}$ For example, define point $\mathrm{A}$ as a point on the pipeline in front of the send transducer and point $\mathrm{B}$, in front of the receive transducer. When the send transducer transmits a pulse, some fraction passes into the slurry, where: 1 ) it is 


\subsubsection{Flow Velocity Profiling with Ultrasonic Doppler Velocimetry}

At the critical velocity in a horizontal pipe, the vertical velocity profile will become slower near the floor as solids segregate and begin to deposit. This technology is likely to be very sensitive to detecting anomalies in the velocity profile that would indicate presence of particle segregation or deposition on the pipe floor. Measuring the velocity across a vertical section may give a strong indication when critical conditions are being approached by the indication of a skewed profile. This velocity may be represented as $\mathrm{U}_{2}$ in Figure 3.1.

An advanced ultrasonic Doppler velocimetry (UDV) method has been developed that provides nondisruptive measurements of a flowing fluid or slurry. The method is based on integration of spatially resolved ultrasonic Doppler backscatter measurements and forward-scatter attenuation measurements. The method provides a flow velocity profile and shear stress values across the diameter of the process pipe for both Newtonian and non-Newtonian fluids. The device is designed for use on a large variety of products, including food products, consumer products, and polymer process streams. A complete description of UDV can be found in U.S. Patent No. 6,871,148 B2 (Morgen et al. 2002).

This Doppler-based system operates by generating a tone burst, a specific number of cycles of a sinusoidal waveform ( $\mathrm{N}$ sinewave cycles) at a specific repetition rate. For this measurement application and material properties of the test medium, the frequency of the sinusoidal waveform selected is typically $1 \mathrm{MHz}$. The 3/8 in. diameter transducer is mounted to a lens that is curved to match the inner diameter of the pipe. Two lens materials PEEK (polyaryletherketone) and Rexolite ${ }^{\mathrm{TM}}$ (a cross linked polystyrene microwave plastic made by C-Lec Plastics, Inc.) are being evaluated. The tone burst signal is applied to an ultrasonic transducer that transmits ultrasound into the material being monitored. The repetition rate is the frequency (rate) at which the tone burst signal is applied to the transducer. After the tone burst (ultrasound) is transmitted into the test material, the same transducer is used to receive ultrasound echoes from scattering particles in the test material. The transducer converts the ultrasound echoes into an electronic signal that is amplified and analyzed.

The UDV system relies on measurement of the Doppler frequency shift of moving particles within the material flowing in the pipe, as shown in Figure 3.2. Using a short ultrasonic pulse system, the crosssectional velocity profile can be obtained from the Doppler shift at each differential range point.

reflected at point $\mathrm{B}, 2$ ) it travels through the slurry and is reflected at point $\mathrm{A}, 3$ ) it is reflected at point $\mathrm{B}, 4$ ) it is reflected at point $A$, etc. Each time the ultrasound reflects at point $A$ or at point B, some fraction of the ultrasound travels through the pipeline wall and an echo is recorded by the transducer. By looking at the multiple echoes, the attenuation can be obtained. It is self-calibrating because, if the pulser voltage changes slightly, each echo is affected in the same manner, and the changes "cancel out." The system can be operated so that the echoes are obtained in the receive transducer in the pitch-catch mode and by the send transducer in the pulse-echo mode. 


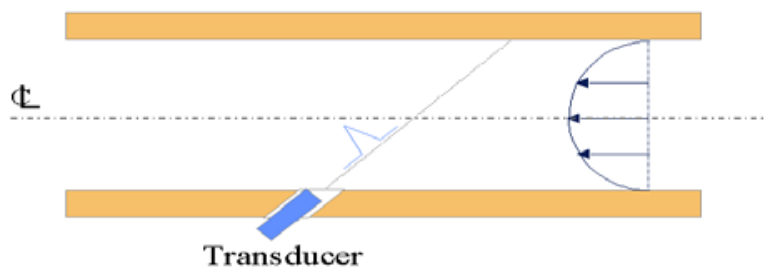

Transmitted Pulse: 5 cycles of $5 \mathrm{MHz}$

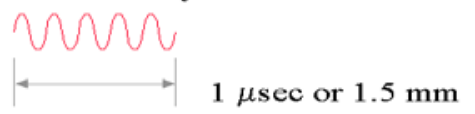

Figure 3.2. Schematic of Typical UDV Application

\subsection{Supporting Instrumentation}

To quantify process conditions supporting instrumentation are installed in the flow loop. In addition, instruments originally installed in the M1 loop to assist with operations will be available as necessary to provide supplementary guidance. These instruments are listed in Table 3.1.

Table 3.1. Summary of Instruments Recommended for Evaluation

\begin{tabular}{|c|c|c|}
\hline Measurement & Instrument & Purpose \\
\hline \multicolumn{3}{|c|}{ PRIMARY MEASUREMENT } \\
\hline \multicolumn{3}{|l|}{ Critical Velocity } \\
\hline & Differential Pressure & Reference $^{(a)(b)}$ \\
\hline & Pulse Echo Ultrasound & Evaluation \\
\hline & Ultrasonic Attenuation & Evaluation \\
\hline & Ultrasonic Doppler Velocimetry & Evaluation \\
\hline & Visual Observation & Reference ${ }^{(\mathrm{c})}$ \\
\hline & High Resolution Imaging & Reference $^{(\mathrm{c})}$ \\
\hline \multicolumn{3}{|c|}{ SECONDARY MEASUREMENTS } \\
\hline \multicolumn{3}{|l|}{ Particle Size } \\
\hline & Lasentec $^{\mathrm{TM}}$ & Guidance $^{(\mathrm{b})}$ \\
\hline \multicolumn{3}{|c|}{ Solids Concentration and Bulk Density } \\
\hline & Coriolis Flowmeter & Reference ${ }^{(b)}$ \\
\hline \multicolumn{3}{|c|}{$\begin{array}{l}\text { (a) The differential pressure method is recommended as a reference during testing. The method could } \\
\text { ultimately be developed for field deployment if warranted. } \\
\text { (b) These instruments were used in the M1 pipe loop and are incorporated into this test configuration. } \\
\text { (c) An optical method is required for reference during testing. Visual observation is limited to } \\
\text { particles above } ~ 50 \mu \text { m and therefore an electronic imaging approach may be required. Early } \\
\text { tests will be tailored to make a determination of the need for this capability }\end{array}$} \\
\hline
\end{tabular}


The planned approach for evaluating the ultrasonic sensor performance would be to compare the critical velocity as determined by the three primary reference techniques (i.e., the differential pressure, high resolution camera and/or visual observation) with the measurements obtained from the ultrasonic sensors. The Lasentec particle size analysis technique is included in the loop as a secondary method for critical velocity determination in the event that the critical velocity cannot be determined by either one of these techniques.

\subsubsection{Coriolis Flow Meter}

The Coriolis flow meter provides a direct measurement of both mass flow rate and fluid density. The flow meter is oriented in vertically upward flow. In the flow meter, process flow is divided between two tube loops that are vibrated by external energy. When fluid is moving through the sensor's tubes, Coriolis forces are induced in both the inlet and outlet legs of both flow tubes. These forces cause the flow tubes to twist in opposition to each other. The flow tubes are of a smaller inner diameter than the pipe; therefore, erosion may occur at a higher rate than in the rest of the pipe, and there is more potential for the line to plug than the rest of the pipe.

The mass flow moving through the inlet legs of the flow tubes generates a Coriolis force that resists the vibration of the flow tubes. As the mass flow moves through the outlet legs, the Coriolis force adds to the vibration of the flow tubes. It is the opposite direction of the Coriolis force between the inlet and outlet legs that result in the twisting motion that is used to measure mass flow rate.

\subsubsection{Thermocouples}

Thermocouples are mounted to track temperature in real time in the process fluid. As required, heat exchange will be used to keep temperature within operating limits.

\subsubsection{Lasentec ${ }^{\mathrm{TM}}$}

The Mettler Toledo Lasentec ${ }^{\mathrm{TM}}$ focused beam reflectance measurement (FBRM) is used to track particle size in real time. The system consists of a D600PST electronics package with a D600S probe. The probe is mounted through a fitting at a 45 deg angle into a vertical up-flow pipe leg. The tip of the probe contains a sapphire window with a rotating laser. As particles pass in front of the probe window, the laser beam is reflected back to the probe tip. Since the speed of the rotating laser is known, the size of the particle can be calculated by the duration of the reflected laser signal. By counting the number of reflected laser signals, a histogram of particle size and counts is obtained. The system has the capability of updating this histogram in 2-second intervals.

Since the laser is randomly scanning across particles, the maximum length of the particle has a lower probability of being measured. For this reason, the system measures the chord-length distribution of the slurry particles rather than the PSD. Consequently, this system is very good for determining when process conditions have changed significantly. For the M1 flow-loop experiments, the Lasentec ${ }^{\mathrm{TM}}$ system $^{\mathrm{T}}$ was used to assess whether significant particle attrition was occurring. For the Lasentec ${ }^{\mathrm{TM}}$ values to be reportable, the system must be performance checked to NIST-traceable standards. Since no chord-length distribution NIST standards currently exist, the Lasentec ${ }^{\mathrm{TM}}$ data was used to determine when changes in the system occur. Consequently, the Lasentec ${ }^{\mathrm{TM}}$ data are categorized "for information only." 


\subsection{Test Approach}

This section describes simulants selected for the tests and describes how tests are designed to generate the data needed to compare performance of the various instruments to each other (see Section 3). Parameters required to assemble a comprehensive and efficient test sequence include the relationship of the instrument response to the phenomenon being assessed, the specific waste properties that influence the instrument response, and the means for varying the flow conditions to generate a range of responses.

The process of conducting testing to determine an accurate settling velocity involves decreasing slurry superficial velocity incrementally to a set point. At the set point, steady state is attained prior to initiating the next incremental velocity reduction. The determination of settling velocity with small slurry particle density difference relative to the slurry carrier fluid as well as large line volumes can dramatically extend the period of performance and overall duration of each test.

\subsection{Simulants}

Properties that affect the mixing of slurries include the undissolved solids density, particle size, liquid density, and rheological parameters such as liquid viscosity, slurry yield stress, and slurry consistency. Four types of simulants were designed to be used during the flow loop and instrumentation tests. These simulant types are progressively more challenging. Monodisperse simulants are described in Section 4.1.1. Binary mixtures and particles with a broad size distribution are described in Section 4.1.2. NonNewtonian simulants are described in Section 4.1.3. Complex simulants are described in Section 4.1.4.

\subsubsection{Noncohesive Monodisperse Particulate Simulants}

Testing with monodisperse particulate benchmarks the measured critical velocity results to prior work and thereby establishes a very defensible basis for the critical velocity results of the new/alternative instrumentation. Monodisperse particulate has a very narrow or single-value size and density distribution. The Oroskar and Turian (1980) correlation for critical velocity used by the WTP and the Tank Operations Contractor is developed from testing with essentially monodisperse particulate slurries. Use of these simulants also provides consistency between test programs such as the WTP M3 Mixing Program (Meyer et al. 2009a) and the waste feed delivery (WFD) Small Scale Mixing \& Sampling Demonstration Program.

Selection of mono-disperse simulants was based on the recently completed M3 testing. Those simulants were based on several particle sizes and two densities. The PSDs were very narrow. The M3 simulants provide a set of solids that have been highly characterized based on PSD and density. In addition the simulants have been characterized for concentration measurements using ultrasonic attenuation sensors. The test parameters of interest for monodisperse particulate are particle size, particle density ratio, solids concentration, and liquid viscosity.

\subsubsection{Noncohesive Particulate Simulants with Size or Density Distributions}

Hanford waste entering the certification loop may contain a very broad distribution of particle sizes and densities. A primary concern is the behavior of the largest particles. These large particles, while 
small in terms of their relative concentration, may dominate the critical velocity requirements disproportionally. The ability of the instruments used to detect the accumulation of the small amounts of heavy particles is critical. Simple tests with binary simulants (such as two densities or two particle sizes) can be conducted readily by combining simulants such as XL Sci-Tech ${ }^{1}$ spherical glass beads which were used during M3 simulants to vary density, or particle size.

Additionally, it is very useful to develop a simulant with a very broad PSD of spherical particles. The PSD should roughly match the Hanford PSD, but with two modifications. First, the PSD should be truncated at some practical minimum size to avoid potential cohesive effects of settled layers, and/or additives should be used eliminate these forces. Secondly, it is beneficial to increase the relative concentration of the heavier particles to quantities that are more readily measurable by the instruments. This is true since testing in the flow loop will involve a relatively small volume of heavy particles, whereas in the certification flow loop much larger actual volume of heavy solids exists.

Selected simulants for binary mixtures are M3 Test Program (Meyer et al. 2009a) solids s1d1 and s1d2 to provide a binary size distribution and s2d1 and s2d2 to vary particle size, where s refers to particle density and $d$ refers to particle diameter. These spheres are also available in colored glass which may be useful for visual observations. For broad size distribution tests a distribution using 6 size bins was constructed with glass beads of various sizes (eg. Potters ${ }^{2}$ Spheriglass ${ }^{\circledR} 11$ and $35 \mu \mathrm{m}$ and Potters Ballotini ${ }^{\mathrm{TM}} 60,125,250$ and $\left.500 \mu \mathrm{m}\right)$. A final mixture simulant was designed based on the broad size distribution with addition of two high density components to create concentration spikes.

The test parameters of interest for binary particulate mixtures are the same as those for monodisperse particulates with the addition of the relative concentration of the two solids. The test parameters of interest for broad distribution particulate slurries are the same as those for monodisperse particulates, with the PSD replacing the monodisperse particle size.

\subsubsection{Non-Newtonian Simulants}

The non-Newtonian simulants are required to evaluate more rheologically complex fluid behavior. The simplest model for a non-Newtonian slurry is the Bingham-plastic model. This model assumes the slurry has both a yield stress and a consistency. Note the definition of consistency is equivalent to the Newtonian viscosity in the limit of zero yield stress. While ICD 19 (Hall 2008) has a suggested yield stress limit of $1 \mathrm{~Pa}$, this is still an open issue within ICD 19, and it is prudent to test to somewhat higher values given the Hanford waste data.

Many previous slurry transport studies have utilized clay slurries to create non-Newtonian mixtures. Pure kaolin has also been extensively characterized and used in testing. Yield stress values ranging from a few Pa to greater than 30 Pa were obtained by varying the water content. The M1 Test Program (Poloski et al. 2009a, b) utilized kaolin slurries with the addition of "coarse” particles. The same approach will be taken in the present evaluation. It should be noted that when using clay slurries the solids loading of the clay is not considered as part of the actual solids loading as the clay particulate will act solely as part of the carrier fluid. The clay concentration is simply adjusted to provide the desired rheology.

\footnotetext{
${ }^{1}$ http://xlscitech.com/, Richland, Washington.

2 http://www.pottersbeads.com/, Malvern, Pennsylvania
} 
The non-Newtonian simulants selected for testing in the flow loop are clay slurries with the addition of spherical particles. The test parameters of interest for the carrier fluid and slurry are yield stress and consistency, as well as particle size, density, and concentration.

Selected simulants are kaolin slurry with addition of particles. Particles selected are the broad continuous PSD composed of six solids; monodisperse solids, and a simulant based on the M1 "Medium" rheology test configuration 8 with Duralum ${ }^{\circledR}{ }^{3}$ an aluminum grit (Poloski et al. 2009a).

\subsubsection{Complex Simulants}

The previously discussed simulants establish the basic functionality of the various instruments tested. Simulants are needed to address how well the instrumentation works with actual waste. Testing will be performed with complex simulants that exhibit many or all of the features of actual waste including broad particle size and density distributions, irregular particle shape, and complex rheology.

The Hanford waste complex simulant is tailored to waste/WTP feed vectors. The AY-102 based simulant is constructed with a clay base with selected coarse particles that are representative for the PSDD for that feed. AY-102 physical simulant constituents: $\mathrm{Zr}(\mathrm{OH})_{4}, \mathrm{Al}(\mathrm{OH})_{3}$, and $\mathrm{Al}_{2} \mathrm{O}_{3}$ (Duralum ${ }^{\circledR}$ 220 grit).

\subsection{Instrument Evaluations}

The objective for testing is to develop information that allows discrimination of performance among candidate instruments and supports selection of one or more instrument being appropriate for the intended application. If measurements of physical or rheological properties, such as PSD, solids concentration, or slurry consistency are performed, data taken in the test loop will be compared to laboratory measurements using standard equipment.

However, the determination of critical velocity is inherently more challenging, as it requires the detection of some unstable condition or feature in a solid-liquid flowing system. Referring to the nomenclature in Figure 3.1, measured "critical” velocities may range from below $\mathrm{U}_{1}$ (the onset of stratification) to below $\mathrm{U}_{3}$ (where a stationary bed is developing). The general approach involves establishing pressure drop as a function of flow velocity or "J-curve," for each simulant, and then superimposing the measurement results on the curve. In this way, the "J-curves" serve as a benchmark and/or framework for evaluating instrument performance. ${ }^{4}$ This approach provides a well-established method for determining critical velocity by using a combination of pressure differential data, measurements, and visual observations.

The critical velocity instruments being evaluated are located in close proximity in the test section as shown in Figure 2.5. This "test section" configuration assures that all candidate instruments experience flow conditions as identical as possible. Data from the instruments is generated concurrently so that direct comparisons can be made.

3 www.washingtonmills.com/, Washington Mills, North Grafton, Massachusetts.

${ }^{4}$ It is not necessary or recommended to establish a complete "J-curve" for each simulant. Rather, only sufficient data should be collected to identify the key attributes of the curve. Much of this data should be generated naturally as a result of evaluating instrument performance. 
Testing occurs in three distinct phases: bench-scale testing which was conducted to support instrument development is described in Section 4.2.1; preliminary testing which was conducted to develop loop operating procedures and define sensor operation is described in Section 4.2.2; and instrument validation testing which is described in Section 4.2.3.

\subsubsection{Bench-Scale Testing}

The purpose of bench-scale testing was to permit definition of components and software configurations for the ultrasonic instrumentation sensors that are being tested in the certification loop. Each of the ultrasonic sensors was configured so that the transducer size, shape, frequency and orientation were appropriately selected for use in the test section. Bench-scale tests to evaluate these parameters were conducted in the lab without fluid flowing in a pipe loop.

To assist with the bench-scale evaluation four simulants were specified which are listed in Table 4.1. These simulants were constructed from readily available components and either matched or were very similar to simulants to be used to evaluate the instruments in the flow loop.

The results of bench-scale testing was used to define sensor components and configurations that should be included in the instrument spool pieces.

Table 4.1. Slurries and Particles Provided for Bench-Scale Testing

\begin{tabular}{|c|c|c|c|c|c|}
\hline $\begin{array}{l}\text { Simulant } \\
\text { Type }\end{array}$ & Base Fluid & Particles & $\begin{array}{l}\text { Nominal Particle } \\
\text { Size }(\mu \mathrm{m})\end{array}$ & $\begin{array}{l}\text { Nominal Density } \\
(\mathrm{g} / \mathrm{ml})\end{array}$ & $\begin{array}{l}\text { Yield Stress } \\
\quad(\mathrm{Pa})\end{array}$ \\
\hline Particle & Water & $\begin{array}{l}\text { M3 s1d2 glass } \\
\text { spheres, } \\
\text { monodisperse }\end{array}$ & 65 & 2.5 & -- \\
\hline Particle & Water & $\begin{array}{l}\text { M3 s2d2 glass } \\
\text { spheres, } \\
\text { monodisperse, } \\
\text { denser }\end{array}$ & 65 & 4.2 & -- \\
\hline Particle & Water & $\begin{array}{l}\text { M3 s1d1 glass } \\
\text { spheres, } \\
\text { monodisperse }\end{array}$ & 170 & 2.5 & -- \\
\hline Particle & Water & $\begin{array}{l}\text { Spheriglass } 5000 \\
\text { glass spheres, } \\
\text { monodisperse }\end{array}$ & 11 & 2.5 & -- \\
\hline Slurry & Kaolin slurry & -- & -- & -- & $\sim 3$ \\
\hline Slurry & Kaolin slurry & -- & -- & -- & $\sim 6$ \\
\hline
\end{tabular}

\subsubsection{Preliminary Testing}

The purpose of preliminary testing is to provide a framework to integrate sensor operation in the certification flow loop and refine test procedures for determining critical velocity in a controlled operating 
environment. During preliminary testing the ultrasonic sensor operating parameters are varied. Transducer frequency and other operating system parameters may be varied to determine which combinations of conditions are recommended for interrogating different simulants. These tests are critical to successfully meeting the overall test objectives and provide the basis for operating conditions to be used during testing.

The specific objectives of the preliminary testing are to:

1. Perform equipment readiness and functional shakedown of flow loop.

2. Verify and synchronize data acquisition systems and

a. verify reproducibility of previous and current testing.

3. Develop strategies for air removal from the slurry mixtures and for introduction of slurry into the flow loop system.

4. Characterize loop performance.

5. Study the influence of broad continuous PSD on the pressure transmitter response during critical velocity determination.

6. Determine if secondary measurement techniques for critical velocity are sufficient or if additional techniques such as inline particle size analysis (Lasentec ${ }^{\mathrm{TM}}$ ) are necessary

7. Determine the conditions for transducer frequencies and other tunable parameters for use with simulant testing

8. Refine techniques to reclaim select simulant components from previously tested slurries for future use

9. Develop test instructions and directions

The tests selected to be performed during the preliminary testing phase use the simulants shown in Table 4.2. Also shown in Table 4.2 is the list of objectives above which will be accomplished by the different tests.

The results of preliminary testing are to understand how the loop and instrumentation should be operated to obtain data from a range of simulant types in an effective, efficient manner, to refine the test procedures and instrument operation, and to provide focus regarding which simulants and tests should be conducted during instrument validation testing. 
Table 4.2. Test Matrix for Preliminary Simulant Studies

\begin{tabular}{|c|c|c|c|c|c|c|c|c|c|}
\hline Simulant Type & $\begin{array}{l}\text { Test } \\
\text { Number }\end{array}$ & Objectives & $\begin{array}{l}\text { Carrier } \\
\text { Fluid }\end{array}$ & Particles & $\begin{array}{l}\text { Particle Size } \\
\mathrm{d}(50) \\
\mu \mathrm{m}\end{array}$ & $\begin{array}{l}\text { Nominal } \\
\text { Density } \\
\text { (g/ml) }\end{array}$ & $\begin{array}{l}\text { Solids } \\
\text { Concentration } \\
\text { (wt\% solids) }\end{array}$ & $\begin{array}{l}\text { Viscosity or } \\
\text { Consistency } \\
\text { (cP) }\end{array}$ & $\begin{array}{l}\text { Yield } \\
\text { Stress } \\
(\mathrm{Pa})\end{array}$ \\
\hline M3 s1d2 & 1,2 & $1-6,8,9$ & Water & Monodisperse & 65 & 2.5 & $\mathrm{~L}=5, \mathrm{M}=10$ & $\mathrm{~L}=1$ & $\mathrm{~L}=0$ \\
\hline M3 s2d2 & 3 & $1-6,8,9$ & Water & Monodisperse & 65 & 4.2 & $\mathrm{M}=10$ & $\mathrm{~L}=1$ & $\mathrm{~L}=0$ \\
\hline $\begin{array}{l}\text { Potters Spheriglass }{ }^{\circledR} \\
5000 \sim 11 \mu \mathrm{m} \\
3000 \sim 35 \mu \mathrm{m} \\
\text { Potters Ballotini }{ }^{\mathrm{TM}} \\
\# 13 \sim 60 \mu \mathrm{m} \\
\# 10 \sim 125 \mu \mathrm{m} \\
\# 6 \sim 250 \mu \mathrm{m} \\
\# 4 \sim 500 \mu \mathrm{m}\end{array}$ & 4,5 & $3,5,6,7,8$, and 9 & Water & $\begin{array}{l}\text { Broad } \\
\text { continuous } \\
\text { PSD }\end{array}$ & $11-500$ & 2.5 & $\begin{array}{l}\mathrm{L}=5, \mathrm{H}=20 \\
6 \text { component } \\
\text { distribution } \\
\sim 11 \mu \mathrm{m}(7) \\
\sim 35 \mu \mathrm{m}(14) \\
\sim 60 \mu \mathrm{m}(29) \\
\sim 125 \mu \mathrm{m} \mathrm{(29)} \\
\sim 250 \mu \mathrm{m}(14) \\
\sim 500 \mu \mathrm{m} \mathrm{(7)}\end{array}$ & $\mathrm{L}=1$ & $\mathrm{~L}=0$ \\
\hline
\end{tabular}




\subsubsection{Instrument Validation Testing}

Instrument validation tests commence after the completion of preliminary testing. For the Instrument Validation Testing simulant property ranges were selected to both span anticipated certification flow loop ranges (assumed to exceed by some amount ICD 19 values) as well as provide measurable and challenging conditions for the instruments. It is important to keep in mind that it is not the actual value of critical velocity during testing that is important, rather it is the ability of the instruments to detect it.

The objective of testing using a range of simulants is to verify the ability of the chosen ultrasonic sensors to detect slurry stratification and sedimentation over a range of slurries with varying physical and rheological properties. The physical and rheological properties varied during the instrument validation testing include: size, shape, and density of the undissolved particulates and the density, viscosity, and yield stress of the carrier fluid or the overall slurry mixture.

It should be noted that it is not clear at the present time whether the short circuit loop can be used for the non-Newtonian simulants. The concern here is whether the rheology can be adequately adjusted in the short circuit loop without requiring frequent depressurization and simulant additions. Test \#14 in Table 4.5 will be used to evaluate whether the short circuit loop can be used for these simulants.

In the following sections the ranges of properties for simulant concentration, rheology, and the simulant test matrix are presented.

\subsubsection{Concentration Ranges}

For solids concentration ranges ICD 19, Table 7, lists the "Maximum solids..." for HLW transfer as $200 \mathrm{~g} / \mathrm{L}$ (Hall 2008). This solids concentration corresponds to a UDS (undissolved solids) mass fraction of 0.17 (50th and 95th percentiles by tank count) for Hanford waste (Meyer et al 2009b). The mass fraction of UDS in AY-102, the WTP commissioning feed tank, is 0.11. The sediment depth in DST feed tanks could be up to 200 inches (Wells and Ressler 2009). The operating limit in the AY and AZ tank farms is 364 inches. With a 50th $\left(95^{\text {th }}\right)$ percentile (by tank count) HLW sediment UDS loading of 0.53 (0.73) (Weber 2009, Wells et al 2007); the maximum homogenized UDS mass fraction is then approximately 0.32 (0.45). Note that this is approximately the sediment concentration in AY-102 and AZ-101 (Wells and Ressler 2009). Based on this information the following ranges were selected for solids concentration: $\mathrm{L}=0.05, \mathrm{M}=0.1$, and $\mathrm{H}=0.2$.

\subsubsection{Rheology Ranges}

The range of simulant rheological properties for the various simulants that will be used in the present evaluation is summarized in Table 4.3. It can be seen from the data in Table 4.3, the viscosity/consistency ranges are not specified. This is because viscosity/consistency and yield stress are interrelated related for clay based simulants. In other words, by controlling the yield strength, the consistency cannot be controlled. 


\subsubsection{Test Matrix}

During the instrument validation tests the simulants are grouped in order of increasing complexity into four categories: 1) Single component simulants include only 1 size solid in either water or glycerin. 2) Mixtures include binary size, binary density and broad particle size distribution in either water or glycerin. 3) Non-Newtonian simulants have a kaolin slurry carrier fluid. 4) Complex simulants are designed to model AY-102 physical constituents. The matrix of simulants to be used during the instrument validation tests is shown in Tables 4.4 and 4.5.

A total of 22 tests will be performed over the course of the preliminary ( 5 tests listed in Table 4.3) and instrument validation (17 tests listed in Tables 4.4 and 4.5) tests to assess the performance of the ultrasonic sensing equipment. These tests are considered to be a minimum set necessary to determine whether one or more of these sensors can be carried forward for further testing and field deployment. The tests are grouped according to simulant type: single component (tests 1-3, 7-9), mixture (tests4, 5, 9-13), non-Newtonian (14-19), and complex (tests 20-22).

Initial tests involve simulants that are monodisperse (very narrow size and density distribution) and have a history of testing on other programs, such as the WTP M1 and M3 programs. Testing with monodisperse particulate serve to benchmark the measured critical velocity results to prior work and thereby establish a very defensible basis for the critical velocity results of the new/alternative instrumentation. Monodisperse simulants, such as glass beads of a specific size, provide an opportunity to identify the critical velocity conditions much more easily than using a simulant with a broad size and/or density distribution, or one that exhibits non-Newtonian behavior. One would expect the critical velocity of monodisperse glass beads to occur within a narrow velocity range and to be sharply identifiable. This approach allows the test engineers to refine procedures and interpret data more accurately before the more difficult conditions are tested.

Table 4.3. Anticipated Rheology Test Ranges

\begin{tabular}{ccccc}
\hline $\begin{array}{c}\text { Consistency } \\
\mathrm{K}(\mathrm{cP})\end{array}$ & $\begin{array}{c}\text { Shear Strength } \\
\tau(\mathrm{Pa})\end{array}$ & Supernatant & $\begin{array}{c}\text { Test Condition Range } \\
\text { Consistency }^{(\mathrm{a})(\mathrm{b})}\end{array}$ & $\begin{array}{c}\text { Test Condition Range } \\
\text { Yield Stress }^{(\mathrm{a})}\end{array}$ \\
\hline 1 & 0 & water & $\mathrm{L}$ & $\mathrm{L}$ \\
$3-10$ & 0 & glycerin & $\mathrm{H}$ & $\mathrm{L}$ \\
$\mathrm{n} / \mathrm{c}^{(\mathrm{a})}$ & $2-3$ & Kaolin & $\mathrm{n} / \mathrm{c}^{(\mathrm{b})}$ & $\mathrm{M}$ \\
$\mathrm{n} / \mathrm{c}^{(\mathrm{a})}$ & 6 & Kaolin & $\mathrm{n} / \mathrm{c}^{(\mathrm{b})}$ & $\mathrm{H}$ \\
\hline
\end{tabular}

(a) Rheological conditions such as (L, H), (L, M) or (M., H) are not expected to occur.

(b) Not controlled; consistency determined by yield stress target.

Test conditions include simulants with physical properties that reflect anticipated ranges of actual waste with an emphasis on property ranges that would likely result in lower critical velocity. For example, if the yield stress is high in a non-Newtonian simulant, the critical velocity will be high as well. Only very large particles would have the potential to segregate. Hence testing non-Newtonian simulants with only smaller particles would provide little benefit.

Test conditions were selected with regard to the type of response generated by each candidate instrument. Devices that employ ultrasonic energy to interrogate the slurry may be affected by solids that 
attenuate the sound energy more than those that do not, and testing would need to explore the sensitivity or limitations that result from that. In addition controlled addition of air will be evaluated to determine what types of mitigation may be required if air would be present during characterization loop operation. 
Table 4.4. Test Matrix for Critical Velocity Tests with Newtonian Simulants

\begin{tabular}{|c|c|c|c|c|c|c|c|c|c|}
\hline $\begin{array}{l}\text { Simulant } \\
\text { Type }\end{array}$ & $\begin{array}{c}\text { Test } \\
\text { Number }\end{array}$ & $\begin{array}{l}\text { Reference/ } \\
\text { Description }\end{array}$ & $\begin{array}{l}\text { Carrier } \\
\text { Fluid }\end{array}$ & Particles & $\begin{array}{c}\text { Particle Size } \\
\mathrm{d}(50) \\
\mu \mathrm{m}\end{array}$ & $\begin{array}{c}\text { Nominal } \\
\text { Density } \\
(\mathrm{g} / \mathrm{ml})\end{array}$ & $\begin{array}{l}\text { Solids Concentration } \\
\text { (wt\% solids) }\end{array}$ & $\begin{array}{l}\text { Viscosity or } \\
\text { Consistency } \\
\text { (cP) }\end{array}$ & $\begin{array}{c}\text { Yield } \\
\text { Stress } \\
(\mathrm{Pa})\end{array}$ \\
\hline \multirow{3}{*}{$\begin{array}{l}\text { Single } \\
\text { Component }\end{array}$} & 6 & M3 s1d1 & Water & Monodisperse & 170 & 2.5 & $M=10$ & $\mathrm{~L}=1$ & $\mathrm{~L}=0$ \\
\hline & 7 & M3 s1d1 & Glycerin & Monodisperse & 170 & 2.5 & $M=10$ & $\mathrm{H}=\sim 10$ & $\mathrm{~L}=0$ \\
\hline & 8 & M3 s1d5 (or smaller) & Water & Monodisperse & 40 & 2.5 & $M=10$ & $\mathrm{~L}=1$ & $\mathrm{~L}=0$ \\
\hline \multirow[t]{4}{*}{ Mixture } & 9,10 & M3 s1d1, s1d2 & Water & Binary size & $65 \& 170$ & 2.5 & $\begin{array}{l}L=5(33,67) \\
H=20(67,33)\end{array}$ & $\mathrm{L}=1$ & $\mathrm{~L}=0$ \\
\hline & 11 & M3 s1d2, s2d2 & Water & Binary density & 65 & $2.5 \& 4.3$ & $\mathrm{H}=20(67,33)$ & $\mathrm{L}=1$ & $\mathrm{~L}=0$ \\
\hline & 12 & $\begin{array}{l}\text { Potters Spheriglass }{ }^{\circledR} \\
5000 \sim 11 \mu \mathrm{m} \\
3000 \sim 35 \mu \mathrm{m} \\
\text { Potters Ballotini }{ }^{\mathrm{TM}} \\
\# 13 \sim 60 \mu \mathrm{m} \\
\# 10 \sim 125 \mu \mathrm{m} \\
\# 6 \sim 250 \mu \mathrm{m} \\
\# 4 \sim 500 \mu \mathrm{m}\end{array}$ & Glycerin & Broad PSD & $11-500$ & 2.5 & 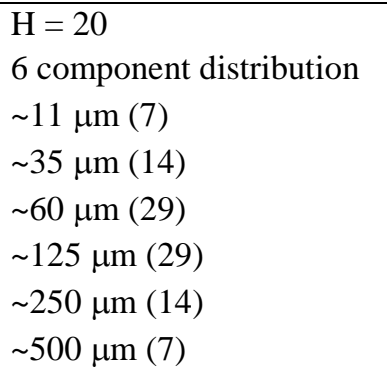 & $\mathrm{H}=\sim 10$ & $\mathrm{~L}=0$ \\
\hline & 13 & $\begin{array}{l}\text { Potters Spheriglass }{ }^{\circledR} \\
5000 \sim 11 \mu \mathrm{m} \\
3000 \sim 35 \mu \mathrm{m} \\
\text { Potters Ballotini }{ }^{\mathrm{TM}} \\
\# 13 \sim 60 \mu \mathrm{m} \\
\# 10 \sim 125 \mu \mathrm{m} \\
\# 6 \sim 250 \mu \mathrm{m} \\
\# 4 \sim 500 \mu \mathrm{m} \\
\text { Add s2d4 } 40 \mu \mathrm{m} \\
\text { s2d2 } \sim 65 \mu \mathrm{m} \\
\text { s2d1 } 170 \mu \mathrm{m}\end{array}$ & Water & $\begin{array}{l}\text { Broad } \\
\text { continuous } \\
\text { PSD and } \\
\text { binary density }\end{array}$ & $11-500$ & $2.5-4.2$ & $\begin{array}{l}\mathrm{H}=20 \\
6 \text { low density components } \\
50 \mathrm{wt} \% \text { total } \\
\sim 11 \mu \mathrm{m}(7) \\
\sim 35 \mu \mathrm{m}(14) \\
\sim 60 \mu \mathrm{m}(29) \\
\sim 125 \mu \mathrm{m}(29) \\
\sim 250 \mu \mathrm{m}(14) \\
\sim 500 \mu \mathrm{m}(7) \\
3 \text { high density } \\
\text { components } \\
50 \text { wt\% total to create } \\
\text { “concentration spikes” } \\
40 \mu \mathrm{m}(60) \\
65 \mu \mathrm{m}(30) \\
170 \mu \mathrm{m}(10)\end{array}$ & $\mathrm{L}=1$ & $\mathrm{~L}=0$ \\
\hline
\end{tabular}


Table 4.5. Test Matrix for Critical Velocity Tests with Non-Newtonian/Complex Simulants

\begin{tabular}{|c|c|c|c|c|c|c|c|c|c|}
\hline $\begin{array}{l}\text { Simulant } \\
\text { Type }\end{array}$ & $\begin{array}{c}\text { Test } \\
\text { Number }\end{array}$ & $\begin{array}{l}\text { Reference/ } \\
\text { Description }\end{array}$ & $\begin{array}{l}\text { Carrier } \\
\text { Fluid }\end{array}$ & Particles & $\begin{array}{c}\text { Particle Size } \\
\mathrm{d}(50) \\
\mu \mathrm{m}\end{array}$ & $\begin{array}{c}\text { Nominal } \\
\text { Density } \\
(\mathrm{g} / \mathrm{ml})\end{array}$ & $\begin{array}{l}\text { Solids Concentration } \\
\text { (wt\% solids) }\end{array}$ & $\begin{array}{l}\text { Viscosity or } \\
\text { Consistency } \\
\text { (cP) }\end{array}$ & $\begin{array}{c}\text { Yield } \\
\text { Stress } \\
(\mathrm{Pa})\end{array}$ \\
\hline \multirow[t]{4}{*}{$\begin{array}{l}\text { Non- } \\
\text { Newtonian }\end{array}$} & 14 & $\begin{array}{l}\text { Kaolin with coarse } \\
\text { solids } \\
\text { Potters Ballotini } \\
\# 8150-212 \mu \mathrm{m} \\
\sim 180 \mu \mathrm{m}\end{array}$ & $\begin{array}{l}\text { Kaolin } \\
\text { slurry }\end{array}$ & Narrow PSD & 180 & 2.5 & $M=10$ & $\mathrm{n} / \mathrm{c}^{(\mathrm{a}, \mathrm{b})}$ & $\mathrm{H}=\sim 6$ \\
\hline & 15,16 & $\begin{array}{l}\text { Kaolin with Potters } \\
\text { Spheriglass }{ }^{\circledR} \\
5000 \sim 11 \mu \mathrm{m} \\
3000 \sim 35 \mu \mathrm{m} \\
\text { Potters Ballotini }{ }^{\text {TM }} \\
\# 13 \sim 60 \mu \mathrm{m} \\
\# 10 \sim 125 \mu \mathrm{m} \\
\# 6 \sim 250 \mu \mathrm{m} \\
\# 4 \sim 500 \mu \mathrm{m}\end{array}$ & $\begin{array}{l}\text { Kaolin } \\
\text { slurry }\end{array}$ & $\begin{array}{l}\text { Broad continuous } \\
\text { PSD }\end{array}$ & $11-500$ & 2.5 & 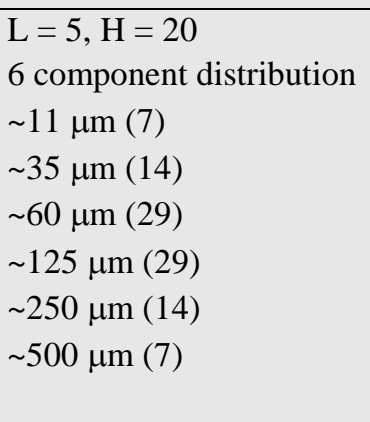 & $\mathrm{n} / \mathrm{c}^{(\mathrm{a})}$ & $\mathrm{H}=\sim 6$ \\
\hline & 17,18 & $\begin{array}{l}\text { Kaolin with coarse } \\
\text { solids } \\
\text { Potters Ballotini }{ }^{\mathrm{TM}} \\
\# 13 \text { 45-90 } \mu \mathrm{m}\end{array}$ & $\begin{array}{l}\text { Kaolin } \\
\text { slurry }\end{array}$ & Monodisperse & 60 & 2.5 & $\mathrm{~L}=5, \mathrm{H}=20$ & $\mathrm{n} / \mathrm{c}^{(\mathrm{a})}$ & $\mathrm{H}=\sim 6$ \\
\hline & 19 & $\begin{array}{l}\text { M1 “Medium } \\
\text { Rheology” test } \\
\text { configuration } 8{ }^{\text {(c) }}\end{array}$ & $\begin{array}{l}\text { Kaolin } \\
\text { slurry }\end{array}$ & $\begin{array}{l}\text { Broad continuous } \\
\text { PSD }\end{array}$ & $\begin{array}{l}3.5-110 \\
{[d(50)=63} \\
\mu m \text { for } \\
\text { Duralum } ®]\end{array}$ & 3.77 & $\mathrm{M}=10$ & $\mathrm{n} / \mathrm{c}^{(\mathrm{a})}$ & $\mathrm{M}=\sim 3$ \\
\hline \multirow[t]{3}{*}{ Complex } & 20 & AY-102 physical ${ }^{(\mathrm{d})}$ & $\begin{array}{l}\text { Kaolin } \\
\text { slurry }\end{array}$ & $\begin{array}{l}\text { Broad continuous } \\
\text { PSD and binary } \\
\text { density }\end{array}$ & $\begin{array}{l}\text { Feed } \\
\text { specific }\end{array}$ & $\begin{array}{l}\text { Feed } \\
\text { specific }\end{array}$ & $\mathrm{M}=10$ & $\mathrm{n} / \mathrm{c}^{(\mathrm{a})}$ & $\mathrm{M}=\sim 3$ \\
\hline & 21 & AY-102 physical ${ }^{(\mathrm{d})}$ & $\begin{array}{l}\text { Kaolin } \\
\text { slurry }\end{array}$ & $\begin{array}{l}\text { Broad continuous } \\
\text { PSD and binary } \\
\text { density }\end{array}$ & $\begin{array}{l}\text { Feed } \\
\text { specific }\end{array}$ & $\begin{array}{l}\text { Feed } \\
\text { specific }\end{array}$ & $\mathrm{L}=5$ & $\mathrm{n} / \mathrm{c}^{(\mathrm{a})}$ & $\mathrm{M}=\sim 3$ \\
\hline & 22 & AY-102 physical ${ }^{(d)}$ & $\begin{array}{l}\text { Kaolin } \\
\text { slurry }\end{array}$ & $\begin{array}{l}\text { Broad continuous } \\
\text { PSD and binary } \\
\text { density }\end{array}$ & $\begin{array}{l}\text { Feed } \\
\text { specific }\end{array}$ & $\begin{array}{l}\text { Feed } \\
\text { specific }\end{array}$ & $M=10$ & $\mathrm{n} / \mathrm{c}^{(\mathrm{a})}$ & $\mathrm{H}=\sim 6$ \\
\hline
\end{tabular}


(a) Not controlled; consistency determined by yield stress target

(b) Test \#14 will be used to determine whether the short circuit loop can be used for all tests involving the non-Newtonian simulants

(c) Poloski et al. (2009), (WTP-RPT-175) Table 4.5

(d) AY-102 physical simulant constituents: $10 \mathrm{wt} \% \mathrm{Zr}(\mathrm{OH})_{4}, 32 \mathrm{wt} \% \mathrm{Al}(\mathrm{OH})_{3}$, and $57 \mathrm{wt} \% \mathrm{Al}_{2} \mathrm{O}_{3}$ (Duralum ${ }^{\circledR} 220$ grit) 


\subsection{Test Procedure}

The formal test procedure is based on lessons learned during the M1 critical velocity testing and insights gained during preliminary testing. The general steps include:

1. Select loop configuration for testing: either Short-Circuit Loop or Standard Loop configuration.

2. Load simulant for testing. The simulant recipes are based on the volume required and test matrix information.

3. Homogenize the simulant. This step includes degassing the simulant and ensuring that solids are adequately wetted and is accomplished by operating the slurry pump.

4. Start pump at maximum target flow rate. Verify flow rate based on Coriolis flow meter reading.

5. Flow/Instrumentation measurements. Assess the state of flow using reference instruments described in Section 3.1, ultrasonic instruments described in Section 3.2, and supporting instrumentation described in Section 3.3. Evaluate whether differential pressure ports need to be flushed.

6. Determine steady state operation. Obtain data for the ultrasonic test instruments and supporting instruments..

7. Decrease flow rate. Repeat steps 5 through 7 until settled solids are visible in clear spool piece.

8. After completion of test, either flush flow loop, reclaim simulant, and clean loop for next simulant or return to step 2 to add additional simulant to conduct a test at higher solids loading. 



\subsection{Data Analysis}

Data reduction and analysis of the test measurements will be conducted to evaluate the effectiveness of the prescribed methodology and individual measurements. The data analysis will include quantitative comparisons of instrument performance at the test conditions and qualitative observations of instrument characteristics that may be important to operations.

Data includes: simulant properties, flow loop operational conditions, instrument readings from reference, ultrasonic, and supporting sensing systems, and observations.

Differential pressure measurement: At steady state there is no change in differential pressure measurement as a function of time.

Visual observation: Both the Short-Circuit Loop and Standard Loop are designed to have the largest diameter pipe and thereby the lowest flow rate in the horizontal test section; therefore, when settled solids are the same in both observation spoolpieces on either side of the test section, steady state should be verified by the differential pressure measurement.

Ultrasonic attenuation: To measure ultrasonic attenuation a series of ultrasonic transducers are placed around the circumference of the pipe in the spool piece perpendicular to pipe flow. When solids are stratified or settled, the sensors oriented horizontally are expected to detect a lower attenuation than sensors oriented vertically or at a 45 degree angle. This sensor is anticipated to be able to detect flow conditions associated with velocities less than or equal to $\mathrm{U}_{1}$, as shown in Figure 3.1.

Pulse echo: In this system an ultrasonic transducer is placed beneath the pipe perpendicular to pipe flow. When solids start to settle on the bottom of the pipe, an interface is detected between the settled (or sliding) particulate and the mobilized particulate based on the ultrasonic backscatter signal. This sensor is anticipated to be able to detect a sliding bed of a certain thickness and bed growth to a stationary bed of solids.

Ultrasonic Doppler velocimetry: In this system an ultrasonic transducer is placed at an angle relative to the flow direction. The system measures the velocity flow profile by analyzing the Doppler shift frequency of moving particles using the ultrasonic backscatter signals received from the transducer. When critical conditions are being approached the velocity profile may become skewed. This sensor may be able to detect flow conditions associated with $U_{2}$ or $U_{3}$ as shown in Figure 3.1.

Lasentec $^{\mathrm{TM}}$ : This instrument is used to detect particle size as the slurry flows past the sensor. For the monodisperse simulants, the sensor would detect simulant degradation over time. Note simulant degradation was not observed during the M1 test program tests. For the polydisperse or bimodal simulants of a single density the sensor is expected to show a decrease in particle size as flow rate is reduced and larger solids settle in the test section. For polydisperse or bimodal simulants of more than one density the change in size distribution should be based on the settling velocity of the particulate.

During data analysis these phenomena will be compared with the readings of the ultrasonic sensors being evaluated to determine whether the sensors provide a consistent response that can be used to track stratification, the onset of critical velocity, and sedimentation. In the simplest manner, it is anticipated that the data analysis would be a straight comparison between the critical velocity as determined by the 
primary reference techniques and the measurement from the ultrasonic sensors. It is possible that the comparison may not be always be straightforward. In such situations, statistical methods to band the uncertainties of critical velocity measurements between the primary instruments and secondary instruments will be utilized to facilitate the necessary comparison. 


\subsection{Waste Minimization/Management}

All waste disposal procedures will be developed with the guidance of the PNNL Environment, Safety, Health, and Quality (ESH\&Q) Department for all materials that will be used in this test program. All waste storage, transportation, and disposal activities will be coordinated by the cognizant space manager (CSM) and approved by the environmental compliance representative (ECR) assigned to the test facility. No staff will dispose of simulant materials or discharge material to the process sewer without the direction of the CSM or ECR. A waste disposal procedure will be generated and approved by the ECR for each simulant before the simulant materials are received or mixed.

Records on the quantity and concentration of the simulant constituents will be maintained during the test program for the individual batches of material to be disposed. Waste quantities and the weight percent of the individual constituents will be required by the ECR for waste designation. The volume of the M1 loop was 66 gal; the volume of the Standard Loop is similar, and the volume of the Short-Circuit Loop is $\sim 40$ gal. In the Standard Loop configuration about 430 gal of simulant is expected to be contained in the mix tank.

It is not expected that spent simulant will be designated as a dangerous waste under WAC 173-303. However should the spent simulants be designated as dangerous waste during certification loop operation, waste disposal activities will be conducted according to the Resource Conservation and Recovery Act, as implemented by the Washington Administrative Code (WAC) 173-303 entitled, "Dangerous Waste Regulations.” For all discharges to ground, PNNL will comply with the Washington Water Pollution Control Regulations, including WAC 173-216, “State Waste Discharge Permit Program,” as well as any specific permit requirements.

The test setup and operations are designed to ensure that all piping and test vessels can be emptied via gravity drain or pumping prior to rinsing/flushing of the vessels. As much of the contents as possible will be removed from the tank using all available systems. Residue remaining in the tank and the associated rinse/flush water will need to be evaluated by the ECR for proper disposal pathways. This evaluation will be documented in the waste disposal procedure.

The rinse/flush water from the tank will be evaluated for potential disposal to the process sewer via the sewer approval process. A predesignation of the rinseate is strongly recommended. If the predesignation of the rinseate indicates a problem with the sewer approval, additional means of removing the product residue may be implemented.

The following steps will be taken to reduce the quantity of waste generated:

- Changes in the volumetric concentration will be made by incrementally increasing the solids loading.

- Solids materials may be recovered and dried to be recycled for repeat tests conducted at different times.

- Some of the materials may be recycled. Separation and recycling will be performed whenever practical.

Prior to both the purchase and disposal of the simulant materials, coordination for the sharing and recycling of simulant materials will be coordinated with other test programs as practical. 



\subsection{References}

Bamberger JA and MS Greenwood. 2001. Development of a Density Sensor for In-Line Real-Time Process Control and Monitoring of Slurries during Radioactive Waste Retrieval and Transport Operations at DOE Sites. PNNL-13719, Pacific Northwest National Laboratory, Richland, WA.

Bamberger JA and MS Greenwood. 2004. "Using ultrasonic attenuation to monitor slurry mixing in real time.” Ultrasonics 42: 145-148.

Bamberger JA, PA Meyer, JR Bontha, CW Enderlin, AP Poloski, JA Fort, ST Yokuda, HD Smith, F Nigl, M Friedrich, DE Kurath, GLL Smith, JM Bates, MA Gerber, and DA Wilson. 2005. Technical Basis for Testing Scaled Pulse Jet Mixing Systems for Non-Newtonian Slurries. PNWD-3551, Battelle-Pacific Northwest Division, Richland, WA.

Greenwood MS, JD Adamson, and JA Bamberger. 2006. “Long-Path Measurements of Ultrasonic Attentuation and Velocity for Very Dilute Slurries and Liquids and Detection of Contaminants.” Ultrasonics 44(Suppl. 1):e461-e466.

Hall MN. 2008. ICD 19 - Interface Control Document for Waste Feed. 24590-WTP-ICD-MG-01-019, Rev 4. River Protection Project, Waste Treatment Plant, Richland, Washington.

Meyer PA, JA Bamberger, CW Enderlin, JA Fort, BE Wells, SK Sundaram, PA Scott, MJ Minette, GL Smith, CA Burns, MS Greenwood, GP Morgen, EBK Baer, SF Snyder, M White, GF Piepel, BG Amidan, A Heredia-Langner, SA Bailey, JC Bower, KM Denslow, DE Eakin, MR Elmore, PA Gauglitz, AD Guzman, BK Hatchell, DF Hopkins, DE Hurley, MD Johnson, LJ Kirihara, BD Lawler, JS Loveland, OD Mullen, MS Pekour, TJ Peters, PJ Robinson, MS Russcher, S Sande, C Santoso, SV Shoemaker, SM Silva, DE Smith, YF Su, JJ Toth, JD Wiberg, XY Yu, and N Zuljevic. 2009a. Pulse Jet Mixing Tests With Noncohesive Solids. PNNL-18098, WTP-RPT-182, Rev. 0, Pacific Northwest National Laboratory, Richland, WA.

Meyer, PA, JA Bamberger, PA Scott, HE Adkins, BE Wells, J Blanchard, KM Denslow, MS Greenwood, GP Morgen. 2009b. Hanford Tank Farms Waste Certification Flow Loop Test Strategy. PNNL-18688, Pacific Northwest National Laboratory, Richland, WA.

Morgen GP, RA Pappas, DM Pfund, WC Weimer, DM Sheen, and BJ Burghard. 2002. "Ultrasonic system and technique for fluid characterization.” U.S. Patent 6,871,148.

Oroskar, AR and RM Turian. 1980. The Critical Velocity in Pipeline Flow of Slurries. AIChE Journal (Vol 26, No. 4) pp550-558.

Poloski AP, HE Adkins, Jr, MJ Minette, J Abrefah, AM Casella, RE Hohimer, F Nigl, JJ Toth, JM Tingey, and ST Yokuda. 2009a. Deposition Velocities of Newtonian and Non-Newtonian Slurries in Pipelines . PNNL-17639, WTP-RPT-175 Rev. 0, Pacific Northwest National Laboratory, Richland, WA.

Poloski AP, ML Bonebrake, AM Casella, MD Johnson, JJ Toth, HE Adkins, Jr, J Chun, KM Denslow, M Luna, and JM Tingey. 2009b. Deposition Velocities of Non-Newtonian Slurries in Pipelines: Complex 
Simulant Testing. PNNL-18316, WTP-RPT-189 Rev. 0. Pacific Northwest National Laboratory, Richland, WA.

Poloski AP, PA Meyer, LK Jagoda, and PR Hrma. 2004. Non-Newtonian Slurry Simulant Development and Selection for Pulse Jet Mixer Testing. PNWD-3495, WTP-RPT-111 Rev. 0, Battelle - Pacific Northwest Division, Richland, WA.

Weber RA. 2009. Methodology and Calculations for the Assignment of Waste Groups for the Large Underground Waste Storage Tanks at the Hanford Site. RPP-10006 Rev. 8, Washington River Protection Solutions LLC, Richland, WA.

Wells, BE and JJ Ressler. 2009. Estimate of the Distribution of Solids Within Mixed Hanford DoubleShell Tank AZ-101: Implications for AY-102. PNNL-18327, Pacific Northwest National Laboratory, Richland, WA.

Wells BE, MA Knight, EC Buck, SK Cooley, RC Daniel, LA Mahoney, PA Meyer, AP Poloski, JM Tingey, WS Callaway III, GA Cooke, ME Johnson, MG Thien, DJ Washenfelder, JJ Davis, MN Hall, GL Smith, SL Thomson, and Y Onishi. 2007. Estimate of Hanford Waste Insoluble Solid Particle Size and Density Distribution. PNWD-3824, WTP-RPT-153, Rev. 0, Battelle-Pacific Northwest Division, Richland, WA. 



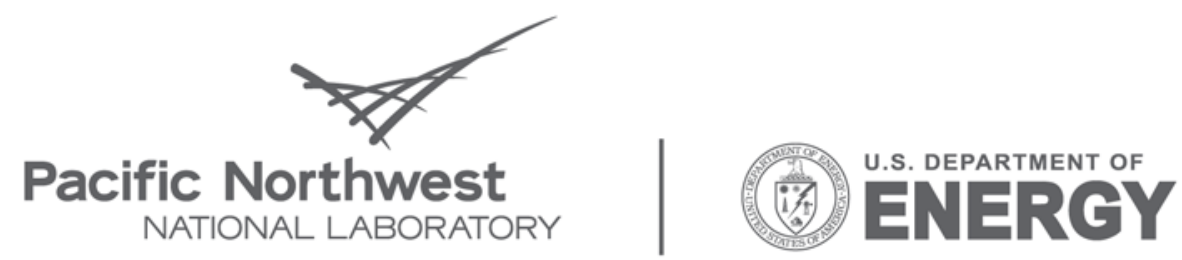

Proudly Operated by Battelle Since 1965

902 Battelle Boulevard

P.O. Box 999

Richland, WA 99352

1-888-375-PNNL (7665)

www.pnl.gov 